January 1997

\title{
Contribution and Proportionate Liability under the Federal Securities Laws in Multidefendant Securities Litigation after the Private Securities Litigation Reform Act of 1995
}

Marc I. Steinberg

Southern Methodist University, Dedman School of Law

Christopher D. Olive

\section{Recommended Citation}

Marc I. Steinberg \& Christopher D. Olive, Contribution and Proportionate Liability under the Federal Securities Laws in Multidefendant Securities Litigation after the Private Securities Litigation Reform Act of 1995, 50 SMU L. REV. 337 (1997)

https://scholar.smu.edu/smulr/vol50/iss1/14

This Article is brought to you for free and open access by the Law Journals at SMU Scholar. It has been accepted for inclusion in SMU Law Review by an authorized administrator of SMU Scholar. For more information, please visit http://digitalrepository.smu.edu. 


\title{
Contribution and Proportionate Liability UNDER THE FedERAL SECURITIES LAWS IN Multidefendant Securities Litigation After the Private SeCurities Litigation Reform ACT OF 1995
}

\author{
Marc I. Steinberg*
} Christopher D. Olive**

\section{TABLE OF CONTENTS}

I. INTRODUCTION ............................. 338

II. THE PRIVATE SECURITIES LITIGATION REFORM ACT OF 1995 ("PSLRA"): OVERVIEW OF TITLE II . .

III. PRIVATE SECURITIES LITIGATION REFORM ACT OF 1995 ("PSLRA"): THE NEW FRAMEWORK FOR ALLOCATION OF LIABILITY UNDER THE FEDERAL SECURITIES LAWS IN MULTIDEFENDANT SECURITIES ACTIONS

A. Limitations on the Joint and Several Liability FRAMEWORK

1. Limitations on Joint and Several Liability as to "Covered" Persons .............................

2. Effect of PSLRA Title II Limitations on Joint and Several Liability Under the 1934 Act and for Outside Directors Under Section 11 of the 1933 Act

a. Reliance in Rule 10b-5 Actions ............ 346

* Rupert and Lillian Radford Professor of Law, School of Law, Southern Methodist University; Visiting Professorial Fellow, Centre for Commercial Law Studies, University of London; Of Counsel, Winstead Sechrest \& Minick; Member, California (inactive), District of Columbia (inactive), Maryland, and Texas Bars.

** B.B.A. (Finance) (Hons.), University of Miami (1992); J.D., Southern Methodist University School of Law (1995); Candidate for LL.M. (Banking \& Finance Law) and Research Fellow, International Financial \& Tax Law Unit, Centre for Commercial Law Studies, University of London (present). Mr. Olive is also a member of the Texas State Bar.

The authors thank Professor George Martinez for his thoughtful comments.

Copyright by Marc I. Steinberg 1996. All rights reserved. 
b. Section 14(a) and Rule 14a-9 Scienter

Requirement ........................ 348

c. Controlling Person Liability Under the 1934 Act ................................... 349

d. Liability of Outside Directors Under Section 11 of the 1933 Act ..................... 350

3. Statutory Contribution Mechanisms for Jointly and Severally Liable "Covered" Persons.............. 351

B. The New Proportionate Liability Framework... 355

C. Statutory Authority For the Issuance of Settlement Bar Orders: Closing the Gaps in Partial Settlements......................... 357

D. Partial Settlements and Judgment Reduction .. 361 1. Pre-PSLRA Partial Settlements: Judgment Reduction Methods in Multidefendant Securities Actions.................................. 362

a. The Pro Rata Method ................... 362

b. The Pro Tanto Method .................. 363

c. The Proportionate Fault Method ........... 366

i. McDermott, Inc. v. AmClyde: The U.S. Supreme Court Adopts the Proportionate Fault Method in Admiralty Law ......... 367

ii. TBG, Inc. v. Bendis: The Tenth Circuit Majority and Justice White Diverge on McDermott ........................ 370

iii. In re Del-Val Financial Corp.: Extending McDermott to Securities Actions for NonSettling Defendant Partial Settlement Claims ............................ 372

d. The "Capped" Proportionate Fault Judgment Reduction Method and Examination of Settling Defendants' Right to Contribution .... 375

2. The PSLRA Judgment Reduction Method ........ 377

E. Reallocation of Liability for UnCollectible

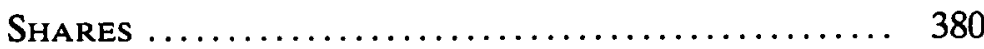

IV. CONCLUSION .............................. 382

\section{INTRODUCTION}

M ultidefendant securities litigation in conjunction with the complexities created by partial settlements and the joint and several liability framework present challenging issues under the federal securities laws. Partial settlements arise in multidefendant securities actions when at least one plaintiff (or plaintiff-class) brings suit against both allegedly primary actors (such as issuers or underwriters and certain per- 
sonnel thereof) and other violators ${ }^{1}$ (such as accountants, attorneys, and their respective entities) ${ }^{2}$ under the liability provisions of the federal securities laws. ${ }^{3}$ These suits frequently include claims for liability under (i) Sections $11,{ }^{4} 12(\mathrm{a})(2)^{5}$ and $15^{6}$ of the Securities Act of 1933 ("Securities Act" or "1933 Act"); (ii) Section 10(b)7 of the Securities Exchange Act of 1934 ("Exchange Act" or "1934 Act"); Rule 10b-58 promulgated thereunder, and Section $20(\mathrm{a})^{9}$ of the same Act, and (iii) various state securities law and common law claims. ${ }^{10}$

Prior to the enactment of the Private Securities Litigation Reform Act of 1995 (the "PSLRA," "Litigation Reform Act," or "1995 legislation"),11 joint and several liability traditionally was recognized under the federal securities laws. ${ }^{12}$ Hence, if co-defendants were adjudged liable in a fed-

1. In light of the U.S. Supreme Court's decision in Central Bank v. First Interstate Bank, 511 U.S. 164 (1994) (holding that no private right of action exists for aiding and abetting liability under $\S 10$ (b) of the Securities Exchange Act and Rule 10b-5 promulgated thereunder), private claims against defendants are primary liability claims, with the exception of "control person" claims under $\$ 15$ of the Securities Act of 1933, 15 U.S.C. $\S 770$ (1988), and $\S 20$ (a) of the Securities Exchange Act of 1934, 15 U.S.C. $\$ 78 t$ (a) (1988), and the possible survival of respondeat superior liability. See, e.g., American Tel. \& Tel. Co. v. Winback and Conserve Program, Inc., 42 F.3d 1421, 1430-31 (3d Cir. 1994).

2. Such defendants may include the issuer and several of the issuer's officers and directors, the issuer's underwriter(s), law firm(s), accounting firm, and certain individual brokers, attorneys, and accountants who assisted in marketing the securities, preparing the prospectus, or certifying the issuer's financial statements. In certain contexts, courts extend liability for such persons as primary violators. See, e.g., In re MTC Elec. Technologies Shareholders Litig., 898 F. Supp. 974, 986 (E.D.N.Y. 1995) (listing cases). Moreover, insurance companies, although not parties to the litigation, may nonetheless be implicated because they insure certain of the subject defendants. See generally MARC I. STEINBERG, Corporate and Securities Malpractice (1992); Joseph P. Monteleone \& Nicholas J. Conca, Directors and Officers Indemnification and Liability Insurance: An Overview of Legal and Practical Issues, 51 Bus. LAw. 573 (1996).

3. As pretrial discovery progresses, motions to dismiss under Federal Rule of Civil Procedure 12(b)(6) and for summary judgment under Federal Rule of Civil Procedure 56 on various points may be jointly filed by several defendants with varying levels of estimated culpability. If denied, the co-defendants may decide to settle with the plaintiff-class and thus become settling defendants at various times during the discovery period.

4. 15 U.S.C. \& 77k (1994).

5. Id. $\$ 77 l(\mathrm{a})(2)$.

6. Id. $\$ 77 \mathrm{o}$.

7. 15 U.S.C. \& 78j(b) (1994). Note that private actions also may be instituted under other 1934 Act provisions, such as $\$ \S 9,14(a), 14(e)$, and 18(a). See generally MARC I. Steinberg, UNDERSTANDING Securities LAW $\$ \S 7.01-.08$. (2d ed. 1996).

8. 17 C.F.R. $\$ 240.10$ b-5 (1996).

9. 15 U.S.C. \& $78 \mathrm{t}(\mathrm{a})$.

10. See generally Joseph C. Long, Blue Sky Law (1985); Marc I. Steinberg, The Ramifications of Recent U.S. Supreme Court Decisions on Federal and State Securities Regulation, 70 Notre DAME L. REv. 489 (1995).

11. Private Securities Litigation Reform Act of 1995, Pub. L. No. 104-67, 109 Stat. 737 (1995) [hereinafter PSLRA, Litigation Reform Act, or 1995 legislation].

12. Joint and several liability is expressly recognized in $\$ \S 11$ and 15 of the 1933 Act and $\$ 20(a)$ of the 1934 Act. However, there exists no express provision in $\S 10(\mathrm{~b})$ of the 1934 Act and Rule 10b-5 promulgated thereunder addressing joint and several liability. As all private actions under Rule $10 \mathrm{~b}-5$ are implied, the theory of joint and several liability has also been implied in this regard. See Herman \& MacLean v. Huddleston, 459 U.S. 375 (1983); Superintendent of Ins. v. Bankers Life \& Casualty Co., 404 U.S. 6 (1971); United States Indus., Inc. v. Touche Ross \& Co., 854 F.2d 1223, 1261 (10th Cir. 1988); Jordan v. Madison Leasing Co., 596 F. Supp. 707, 711 (S.D.N.Y. 1984). Joint and several liability 
eral securities action, plaintiffs were entitled to recover the total judgment from any of the subject defendants. Not surprisingly, some codefendants had "deeper pockets" than others. Thus, settlements in federal securities litigation often were driven by certain co-defendants' concerns of potentially becoming jointly and severally liable for all actual damages of the plaintiffs while only having marginal culpability relative to the alleged violations. ${ }^{13}$ In this respect, such settling defendants clearly desired to remove themselves from future liability in the ongoing litigation.

Other defendants, however, may decline to settle with the plaintiffs and thus remain in the litigation as non-settling defendants. The non-settling defendants accordingly press on with discovery to support their various defenses and counterclaims for presentation at trial. As discovery unveils facts which cause counsel for the non-settling defendants to estimate the liability exposure of their respective clients as well as of other defendants (and in order to preserve any rights their clients may assert against the settling defendants as culpable participants), the non-settling defendants may file cross-claims for contribution and indemnity against the settling defendants and other nonparties who allegedly either caused or contributed to the plaintiff-class losses. Moreover, the settling defendants whose culpability to the plaintiff-class is estimated by subject counsel to be relatively low may consider filing contribution and indemnification crossclaims against several of the non-settling defendants and other nonparties. ${ }^{14}$

Prior to enactment of the 1995 legislation, key legal issues involved in the partial settlement analysis remained largely unsettled. Conflicting precedent existed on several of the more important partial settlement issues, and some recent cases served to confuse, rather than clarify, the inquiries involved in these issues. These issues and conflicts were exacerbated by the joint and several liability scheme, which many parties and

extends to control persons through $\S 15$ of the 1933 Act and $\S 20(a)$ of the 1934 Act, respectively.

13. These defendants often recognized that even if serious questions existed as to their actual liability to the plaintiff-class, the potentially overwhelming financial liability in securities actions under the joint and several liability regimen presented them with a socalled Hobson's Choice: "Should they take the settlement knowing that they may have legitimate chances of winning at trial or should they face the possibility of an exorbitant jury verdict?" See Vincent P. Liberti, Joint and Several Liability Under Rule 10b-5: The Apportionment of Liability for Contribution Claims Involving Non-Settling Defendants, 7 DePaul Bus. L.J. 45, 62-63 (1994). A number of commentators have asserted that more often than not settlement values in such cases do not reflect the merits. See, e.g., Janet C. Alexander, Do the Merits Matter? A Study of Settlements in Securities Class Actions, 43 STAN. L. REv. 497 (1991). More recently, however, some commentators have taken the opposite view. See, e.g., Joel Seligman, The Merits Still Matter: A Rejoinder to Professor Grundfest's Comment, Why Disimply?, 108 HARV. L. REv. 748 (1995).

14. Note that enactment of the Litigation Reform Act impacts significantly these strategies with respect to claims covered by the 1995 legislation as well as those claims that, although not within the PSLRA's scope, are construed in an identical manner due to application of the legislation's rationale. 
commentators alike deplored as resulting in unfair treatment in partial settlement cases.

The nature and status of partial settlement issues under the federal securities laws, and in particular under the 1934 Act, changed in December 1995, when the U.S. Congress overrode President Clinton's veto and enacted the Private Securities Litigation Reform Act of 1995.15 The PSLRA represented the final product of several bills and voluminous testimony from the professional and academic communities that had been ongoing for at least two years, and introduced many important amendments to the federal securities, laws, the effects of which will undoubtedly remain the focus of contemporary debate in efforts to keep the U.S. securities markets healthy and competitive in the international financial marketplace. ${ }^{16}$ Title II of the PSLRA, the focus of this Article, was drafted primarily to address the issues presented by the joint and several liability framework and the dispersed common law precedent concerning partial settlements.

\section{THE PRIVATE SECURITIES LITIGATION REFORM ACT OF 1995 ("PSLRA"): OVERVIEW OF TITLE II}

Title II of the PSLRA resolved a majority of the issues left open by federal case law concerning partial settlements in the Exchange Act setting. These important provisions, however, seemingly have been thus far overshadowed by the Title II provisions which establish a new proportionate liability framework for 1934 Act violations meeting the standard of recklessness, thus confining imposition of joint and several liability under the 1934 Act to an actual knowledge standard. The most dramatic effect of these changes is to limit the liability of peripheral defendants who are likely targets in securities class action lawsuits. Viewed as "deep pockets" and having procured insurance coverage, these defendants are often professionals, such as accountants, lawyers, and underwriters, who may have strong defenses available to preclude liability but nonetheless have every incentive to settle expeditiously, thus protecting the financial integrity of their businesses and themselves from joint and several liability. Recognizing the "strike suit" abuses against these defendants, Congress explicitly sought to "reduce the settlement value" of cases filed against these types of defendants. ${ }^{17}$ Thus, a principal focus of Title II is to remove the powerful incentives of such defendants to settle.

The Litigation Reform Act amends the 1934 Act to add new Section $21 \mathrm{D}(\mathrm{g})$ thereto. ${ }^{18}$ This new section (1) circumscribes the scope of the

15. See generally PSLRA, supra note 11. Section 201 of Title II of the PSLRA, the focus of this Article, has been codified. See $\$ 21 \mathrm{D}(\mathrm{g})$ of the Exchange Act, 15 U.S.C. \& $78 \mathrm{u}-4(\mathrm{~g})(1996)$.

16. See, e.g., Symposium, 24 SEC. REG. L.J. 115-79 (1996).

17. See S. ReP. No. 104-98, 104th Cong., 1st Sess. (1995) [hereinafter SENate REPORT]. See generally John W. Avery, Securities Litigation Reform: The Long and Winding Road to the Private Securities Litigation Reform Act of 1995, 51 Bus. Law. 335, 362 (1996).

18. 15 U.S.C. $\& 78 \mathrm{u}-4(\mathrm{~g})$. 
current joint and several liability scheme; (2) creates a proportionate liability framework for actions brought against multiple defendants under the Exchange Act or against "outside directors" of the issuer whose securities are the subject of an action under Section 11 of the Securities Act; and (3) clarifies several issues relating to partial settlements in federal securities actions. ${ }^{19}$

First, the PSLRA limits the application of joint and several liability for damages to apply only if the trier of fact specifically determines that the defendant in question "knowingly committed" a violation of the Exchange Act (or, if an outside director, of Section 11 of the Securities Act). The term "knowingly committed" requires actual knowledge as the scienter standard, expressly rejecting reckless conduct as a "knowing" violation. ${ }^{20}$ Further, the legislation codifies the right to contribution among such joint tortfeasors recognized by the Supreme Court in Musick, Peeler \& Garrett v. Employers Insurance. ${ }^{21}$ Under this framework, the legislation provides that the liability of such defendants is to be premised upon findings of percentage of responsibility as to each jointly and severally liable defendant. ${ }^{22}$

Second, by implication, in all 1934 Act actions wherein the "knowingly committed" scienter standard cannot be proven by the plaintiff but a lesser culpability standard (such as recklessness) may be shown, the statute creates a proportionate liability regime and (with certain exceptions) restricts liability for damages solely to that portion of the judgment that corresponds to the percentage of such defendant's responsibility for plaintiffs' losses. ${ }^{23}$ In addition, if certain individually liable defendants' shares of liability are uncollectible due to insolvency or some other reason, the statute requires additional proportionate contributions either from the jointly and severally liable defendants or, if still uncollectible, from other proportionately liable defendants for those uncollectible shares in certain specified circumstances. ${ }^{24}$

The PSLRA further provides specific guidelines for determining the percentage of each defendant's responsibility for damages in the form of directing the court (1) to instruct the jury to answer special interrogatories; or (2) where there is no jury, to itself make special findings with respect to multiple defendants on specific issues. Such issues are to in-

19. Id. See generally Andrew J. Pincus, Allocation of Damages: Proportionate Liability and Contribution, Insights, Feb. 1996, at 20.

20. PSLRA, supra note $11, \S 21 \mathrm{D}(\mathrm{g})(2)(\mathrm{A}), 21 \mathrm{D}(\mathrm{g})(10)(\mathrm{B}),(\mathrm{C}), 15$ U.S.C. $\S 78 \mathrm{u}-$ $4(\mathrm{~g})(2)(\mathrm{A}), 78 \mathrm{u}-4(\mathrm{~g})(10)(\mathrm{B}),(\mathrm{C})$.

21. 508 U.S. 286 (1993). See generally Barbara Moses \& Ronit Setton, Contribution Under Rule 10b-5, 26 REv. SEC. \& COMM. REG. 159 (1993).

22. See PSLRA, supra note $11, \S 21 \mathrm{D}(\mathrm{g})(8), 15$ U.S.C. $\S 78 \mathrm{u}-4(\mathrm{~g})(8)$.

23. Id. $\S 21 \mathrm{D}(\mathrm{g})(2)(\mathrm{B})(\mathrm{i}), 15$ U.S.C. $\$ 78 \mathrm{u}-4(\mathrm{~g})(2)(\mathrm{B})(\mathrm{i})$.

24. Id. $\$ 21 \mathrm{D}(\mathrm{g})(4), 15$ U.S.C. $\$ 78 \mathrm{u}-4(\mathrm{~g})(4)$. For example, a "reckless" violator may be jointly and severally liable in certain circumstances where the plaintiff is an individual whose recoverable damages exceed $10 \%$ of such plaintiff's net worth and such plaintiff's net worth is less than $\$ 200,000$. For further discussion, see infra notes 197-205 and accompanying text. 
clude, among other things, the percentage of responsibility of each defendant and whether the defendant "knowingly committed" violations so as to properly place that defendant within the joint and several liability scheme. ${ }^{25}$

Third, the PSLRA evidently brings an end to the controversy generated by several recent decisions addressing issues of partial settlements in 1934 Act federal securities actions by providing for the discharge of all claims for contribution brought by any other persons, whether or not such persons have themselves settled with the plaintiff, against any defendant that has settled any such private action at any time prior to judgment. Moreover, the section requires the implementation of a settlement bar order by the court constituting the discharge of all obligations to the plaintiff of the settling defendant "arising out of the action." 26 The legislation makes clear that such bar orders apply to contribution actions brought by and against the settling defendant. ${ }^{27}$ Note, however, that these provisions apply to actions brought under the Exchange Act, thereby leaving their impact on other federal securities suits unsettled. ${ }^{28}$

In addition, the PSLRA provides for a new judgment reduction method applicable in multidefendant partial settlement cases under the 1934 Act. This method serves to reduce the plaintiff's subsequent judgment against any nonsettling defendant by the greater amount of either (1) the proportionate responsibility of the settling defendant as determined by the court or jury, or (2) the amount that such a settling defendant has already paid to the plaintiff pursuant to the respective settlement agreement. ${ }^{29}$ This particular judgment reduction method evidently eliminates the controversy engendered by the Supreme Court's decision in McDermott, Inc. v. AmClyde, ${ }^{30}$ which adopted the proportionate fault method as the proper judgment reduction method in admiralty cases and was extended to the federal securities context by several federal courts. ${ }^{31}$ This judgment reduction method, however, applies on its face only to 1934 Act actions. ${ }^{32}$

25. See PSLRA, supra note $11, \S 21 \mathrm{D}(\mathrm{g})(3), 15$ U.S.C. $\& 78 \mathrm{u}-4(\mathrm{~g})(3)$.

26. Id. \& $21 \mathrm{D}(\mathrm{g})(7), 15$ U.S.C. $\$ 78 \mathrm{u}-4(\mathrm{~g})(7)$.

27. Id. \& $21 \mathrm{D}(\mathrm{g})(7)$ (i)-(ii), 15 U.S.C. $\$ 78 \mathrm{u}-4(\mathrm{~g})(7)(\mathrm{i})$-(ii).

28. See Pincus, supra note 19 , at 20.

29. See PSLRA, supra note $11, \S 21 \mathrm{D}(\mathrm{g})(7)(\mathrm{B}), 15$ U.S.C. $\S 78 \mathrm{u}-4(\mathrm{~g})(7)(\mathrm{B})$

30. 511 U.S. 202 (1994). See Alan R. Friedman, Contribution and Partial Settlements in Securities Fraud Actions in Light of McDermott, Inc. v. AmClyde, 23 SEC. REG. L.J. 143 (1995).

31. See infra notes $135-76$ and accompanying text.

32. See Walter Rieman et al., The Private Securities Litigation Reform Act of 1995: A User's Guide, 24 SEC. REG. L.J. 143, 172-74 (1996). 


\section{PRIVATE SECURITIES LITIGATION REFORM ACT OF 1995 ("PSLRA"): THE NEW FRAMEWORK FOR ALLOCATION OF LIABILITY UNDER THE FEDERAL SECURITIES LAWS IN MULTIDEFENDANT SECURITIES ACTIONS}

As set forth above, Title II of the PSLRA, applying to specifically defined "covered persons," impacts private actions alleging 1934 Act claims as well as Securities Act Section 11 claims against outside directors. The term "covered persons" is defined in two parts. First, a covered person includes a defendant in any private action "arising under" the 1934 Act. ${ }^{33}$ Second, a covered person includes a defendant in any private action arising under Section 11 of the 1933 Act who is an "outside director" of the subject issuer. ${ }^{34}$ The phrase "outside director" is not defined in the Act, and is to be defined at some point in the future by SEC rule or regulation. ${ }^{35}$ The following discussion provides an analysis of the Title II provisions and how these provisions either clarify, amend, or eliminate portions of the common law related to partial settlements.

\section{A. Limitations on the Joint and Several LIABILITY FRAMEWORK}

\section{Limitations on Joint and Several Liability as to "Covered" Persons}

The most powerful aspects of the 1995 legislation's Title II amendments are the limitations imposed upon joint and several liability for private actions brought under the 1934 Act and the introduction of a new proportionate liability regimen. In short, while retaining joint and several liability for defendants who with actual knowledge engage in violations of the 1934 Act, the PSLRA adopts a modified proportionate liability scheme for defendants found to be less culpable. ${ }^{36}$ The PSLRA thus

33. See PSLRA, supra note $11, \S 21 \mathrm{D}(\mathrm{g})(10)(\mathrm{C})(\mathrm{i}), 15$ U.S.C. $\S 78 \mathrm{u}-4(\mathrm{~g})(10)(\mathrm{C})(\mathrm{i})$.

34. Id. $\S 21 \mathrm{D}(\mathrm{g})(10)(\mathrm{C})(\mathrm{ii}), 15$ U.S.C. $\& 78 \mathrm{u}-4(\mathrm{~g})(10)(\mathrm{C})(\mathrm{ii})$.

35. Id. $\$ 21 \mathrm{D}(\mathrm{g})(10)$ (D), 15 U.S.C. $\S 78 \mathrm{u}-4(\mathrm{~g})(10$ (D). Title II is not to be applied retroactively. Section 202 of Title II provides that it shall not affect or apply to any private action arising under the securities laws commenced before and pending on the date of enactment, which as previously noted was December 22, 1995. Section 203 of Title II further provides that nothing in the PSLRA or the amendments made by it will be deemed to create or ratify any implied private right of action, or to prevent the SEC from otherwise restricting or regulating private actions under the 1934 Act.

36. The Senate Committee on Banking, Housing, and Urban Affairs heard considerable testimony about the impact of joint and several liability on private actions under the federal securities laws. Former SEC Commissioner J. Carter Beese, Jr., observed that "[t]his principle has a legitimate public policy purpose, but, in practice, it encourages plaintiffs to name as many deep-pocket defendants as possible, even though some of these defendants may bear very little responsibility for any injuries suffered by the plaintiff." Testimony of Former SEC Comm'r J. Carter Beese, Jr., Chairman of the Capital Markets Regulatory Reform Project Ctr. for Strategic and Int'l Stud., Before the Sec. Subcomm. of the Senate Comm. on Banking, Housing, and Urban Affairs, Mar. 2, 1995, available in LEXIS, Legis Library, CNGTST File [hereinafter Testimony of J. Carter Beese, Jr.]. He noted that "[a]s a result, whenever a company is sued under Rule 10b-5, there is a strong likelihood that lawyers, accountants, underwriters and directors will be sued, as well." Id. Several other witnesses, including former SEC Chairmen David S. Ruder and Richard C. 
modifies the former joint and several liability framework in an attempt to eliminate perceived unfairness and to "[r]econcile the conflicting interests of investors in a manner designed to best protect the interests of all investors, those who are plaintiffs in a particular case, those who are investors in the defendant company, and those who invest in other companies." 37

The PSLRA provides that any covered person against whom a final judgment is entered in a private action shall be jointly and severally liable for damages only if the trier of fact specifically determines that such covered person knowingly committed a violation of the securities laws. ${ }^{38}$ The PSLRA further provides a special definition for this italicized phrase, and splits the definition to fit two different aspects of conduct. First, with respect to an action that is based on an untrue statement of material fact or omission of a material fact necessary to make the statement not misleading, a covered person "knowingly commits a violation of the securities laws" if

(i) [T] hat covered person makes an untrue statement of a material fact, with actual knowledge that the representation is false, or omits to state a fact necessary in order to make the statement made not misleading, with actual knowledge that, as a result of the omission, one of the material representations of the covered person is false; and (ii) persons are likely to reasonably rely on that misrepresentation or omission. ${ }^{39}$

Second, with respect to an action that is based on any other conduct not described in the first instance, a covered person "knowingly commits a violation of the securities laws" if that covered person engages in such conduct with "actual knowledge of the facts and circumstances that make the conduct of that covered person a violation of the securities laws." 40

In light of the "actual knowledge" standard set forth by these provisions, and for purposes limited only to the newly circumscribed joint and several liability framework, the PSLRA unambiguously provides that reckless conduct by a covered person will not be construed as a "knowing violation of the securities laws" by that covered person. ${ }^{41}$ Hence, although proof of reckless conduct suffices for purposes of the scienter requirement to invoke liability under Section 10(b) and Rule 10b-5

Breeden and former SEC Commissioner Charles C. Cox, likewise acknowledged this issue. See SENATE REPORT, supra note 17 , at 20 \& n.61. In short, the Senate Report focused on reducing (i) the pressure to settle, (ii) the burdens of legal fees and settlement costs, and (iii) insurance premiums, with particular focus on accounting firm liability. The SENATE REPORT further acknowledged that the six largest accounting firms in 1992 faced $\$ 10$ billion in Rule 10b-5 claims, and that their gross audit-related litigation costs amounted to $\$ 783$ million, more than $14 \%$ of their audit revenues for that year. SENATE REPORT, supra note 17 , at $21-22$.

37. Id. at 22 .

38. PSLRA, supra note $11, \S 21 \mathrm{D}(\mathrm{g})(2)(\mathrm{A}), 15$ U.S.C. $\S 78 \mathrm{u}-4(\mathrm{~g})(2)(\mathrm{A})$.

39. Id. $\$ 21 \mathrm{D}(\mathrm{g})(10)(\mathrm{A})(\mathrm{i})(\mathrm{I}-\mathrm{II}), 15$ U.S.C. $\$ 78 \mathrm{u}-4(\mathrm{~g})(10)(\mathrm{A})(\mathrm{i})(\mathrm{I}-\mathrm{II})$.

40. Id. $\$ 21 \mathrm{D}(\mathrm{g})(10)(\mathrm{A})(\mathrm{ii}), 15$ U.S.C. $\$ 78 \mathrm{u}-4(\mathrm{~g})(10)(\mathrm{A})(\mathrm{ii})$. Note that the language used in the text quotes the statute.

41. Id. § $21 \mathrm{D}(\mathrm{g})(10)(\mathrm{B}), 15$ U.S.C. $\S 78 \mathrm{u}-4(\mathrm{~g})(10)(\mathrm{B})$. 
promulgated thereunder, ${ }^{42}$ such culpability fails to bring the covered person within the new joint and several liability framework. ${ }^{43}$ Thus, a key effect of the provisions limiting joint and several liability is to help shield professional groups from astronomical liability. ${ }^{44}$

\section{Effect of PSLRA Title II Limitations on Joint and Several Liability Under the 1934 Act and for Outside Directors Under Section 11 of the 1933 Act}

\section{a. Reliance in Rule 10b-5 Actions}

A Rule 10b-5 plaintiff, in order to satisfy the causation requirement thereunder, must generally show both "loss causation" and "transactional causation." 45 Loss causation is proved through a requisite showing that the harm suffered by the plaintiff actually resulted from the defendant's wrongdoing. ${ }^{46}$ Transactional causation, on the other hand, represents the nexus between the investor's decision to enter into the transaction and the alleged wrongdoing. ${ }^{47}$ In this regard, the transactional causation analysis necessarily entails satisfaction of the reliance requirement, which mandates a showing that the alleged Rule $10 \mathrm{~b}-5$ violation under consideration caused the plaintiff to engage in the transaction. ${ }^{48}$ Hence, in most Rule $10 \mathrm{~b}-5$ cases the plaintiff must establish that he or she "justifiably

42. In Ernst \& Ernst v. Hochfelder, the Supreme Court held that proof of scienterthe intent to deceive or defraud-is a prerequisite to liability in a private action under Rule 10b-5. Ernst \& Ernst v. Hochfelder, 425 U.S. 185, 193 (1976). A question left open by the Hochfelder Court is whether reckless conduct constitutes scienter for purposes of $\S 10$ (b) and Rule 10b-5. Overwhelmingly, the lower federal courts have concluded that recklessness satisfies the scienter requirement. See, e.g., Fine v. American Solar King Corp., 919 F.2d 290, 294 (5th Cir. 1990); Marc I. Steinberg, Securities Regulation: LIABILITIES AND REMEDIES $\$ 7.02$ (1996) (citing cases).

43. See PSLRA, supra note $11, \S 21 \mathrm{D}(\mathrm{g})(2)(\mathrm{A}), 15$ U.S.C. $\$ 78 \mathrm{u}-4(\mathrm{~g})(2)(\mathrm{A})$. Also, the 1995 legislation provides that the procedure for allocation of damages under the joint and several liability scheme is not to be disclosed to members of the jury. Id. $\$ 21 \mathrm{D}(\mathrm{g})(6), 15$ U.S.C. $\$ 78 \mathrm{u}-4(\mathrm{~g})(6)$.

44. Arthur Levitt, Chairman of the SEC, stated in congressional testimony that the actual knowledge standard "would virtually foreclose recovery against attorneys, accountants, and financial advisers" in the context of joint and several liability. Testimony of Arthur Levitt, Chairman of the SEC, Before the Subcomm. on Telecomm. and Fin. of the House Comm. on Commerce, Feb. 10, 1995, available in LEXIS, Legis Library, CNGTST File (observing that this reduction of liability may in fact reduce the degree to which such professional advisers encourage full and complete disclosure by their clients) [hereinafter House Testimony of Arthur Levitt]. See also Testimony of Mark J. Griffin, Director, Div. of Sec., Utah Dep't of Commerce, on Behalf of the N. Am. Sec. Admin'r Ass'n, Before the Subcomm. on Sec. of the Senate Comm. on Banking, Housing, and Urban Affairs, Mar. 22, 1995, available in LEXIS, Legis Library, CNGTST File (raising similar concerns on the effect of shielding professional groups from liability); Testimony of William S. Lerach, Milberg Weiss Bershad Hynes \& Lerach, Before the Subcomm. on Telecomm. and Fin. of the House Comm. on Commerce, Jan. 19, 1995, available in LEXIS, Legis Library, CNGTST File (also raising concerns on the effect of shielding professional groups from liability).

45. See, e.g., Citibank, N.A. v. K-H Corp., 968 F.2d 1489, 1495 (2d Cir. 1992).

46. See, e.g., Manufacturers Hanover Trust Co. v. Drysdale Sec. Corp., 801 F.2d 13, 20 (2d Cir. 1986), cert. denied, 479 U.S. 1066 (1987).

47. Id. 1992).

48. See, e.g., Litton Indus. v. Lehman Bros. Kuhn Loeb, Inc., 967 F.2d 742, 747 (2d Cir. 
relied" on the misleading statement. This burden can be satisfied, for example, by proof of the plaintiff's actual and reasonable reliance or by a showing that the subject securities traded in an efficient market. ${ }^{49}$

Positive proof of reliance, however, may not be required of the plaintiff in certain cases premised upon fraudulent omissions. In such instances, upon demonstrating the materiality of the nondisclosure, the plaintiff may enjoy a presumption of reliance which may be rebutted by the defendant. 50

The two-pronged definition of the phrase "knowingly committed a violation of the securities laws," which is incorporated into the language of the joint and several liability provisions of the PSLRA, apparently is designed to address two separate categories of claims. The language of the first prong of the definition may be read to encompass claims brought under the second subparagraph of Rule $10 \mathrm{~b}-5$ as well as certain other 1934 Act claims that focus on misrepresentations and half-truths. ${ }^{51}$ The second prong of the definition may be interpreted to address other private actions within the scope of Rule 10b-5 and other applicable Exchange Act provisions. ${ }^{52}$ Moreover, in singling out claims brought under the second subparagraph of Rule $10 \mathrm{~b}-5$, the definition arguably incorporates a "reasonable reliance" requirement that must be met to bring a covered person within the joint and several liability scheme. ${ }^{53}$ The ques-

49. See, e.g., Basic, Inc. v. Levinson, 485 U.S. 224, 243 (1988). See also Brown v. E.F. Hutton Group, Inc., 991 F.2d 1020 (2d Cir. 1993); Zobrist v. Coal X, Inc., 708 F.2d 1511 (10th Cir. 1983); STEInBERG, supra note 42, §\$ 7.03, 7.05.

50. See, e.g., Affiliated Ute Citizens v. United States, 406 U.S. 128, 153-54 (1972)

Under the circumstances of this case, involving primarily a failure to disclose, positive proof of reliance is not a prerequisite to recovery. All that is necessary is that the facts withheld be material in the sense that a reasonable investor [would] have considered them important in the making of this decision. ... This obligation to disclose and this withholding of a material fact establish the requisite element of causation in fact.

A number of courts have found that the Affiliated Ute presumption of reliance is not applicable in causes of action brought under the second subparagraph of Rule 10b-5, involving primarily a material misstatement or failure to state a fact necessary to make a statement not materially misleading. See, e.g., Huddleston v. Herman \& MacLean, 640 F.2d 534, 547-49 (5th Cir. 1981), aff'd in part and rev'd in part, on other grounds, 459 U.S. 375 (1983). It is, therefore, necessary to characterize the facts in a Rule 10b-5 case as involving either primarily a failure to disclose, implicating the first or third subparagraph of the Rule and invoking the Affiliated Ute presumption of reliance, or, on the other hand, primarily a misstatement or failure to state a fact necessary to make those statements made not misleading, classified under the second subparagraph of the Rule and as to which no presumption of reliance is applicable.

Id. at 548 (emphasis added). In addition, the Affliated Ute Court and other courts applying the presumption of reliance have found that it is not applicable unless there exists on behalf of the defendant a duty to disclose the information. See, e.g., Affiliated Ute, 406 U.S. at 154; Brass v. American Film Technology, Inc., 987 F.2d 142, 151 (2d Cir. 1993).

51. See PSLRA, supra note $11, \S 21 \mathrm{D}(\mathrm{g})(10)(\mathrm{A})(\mathrm{i})(\mathrm{I}), 15$ U.S.C. $\$ 78 \mathrm{u}-4(\mathrm{~g})(10)(\mathrm{A})(\mathrm{i})$ (I). This prong also may cover certain other Exchange Act claims, such as those brought for violations of $\S 14(\mathrm{e}), 15$ U.S.C. $\$ 78 \mathrm{n}(\mathrm{e})$, and SEC Rule 14a-9, 17 C.F.C. $\S 240.14 \mathrm{a}-9$.

52. PSLRA, supra note $11, \S 21 \mathrm{D}(\mathrm{g})(10)(\mathrm{A})(\mathrm{ii}), 15$ U.S.C. $\$ 78 \mathrm{u}-4(\mathrm{~g})(10)(\mathrm{A})$ (ii). For example, certain Exchange Act $\$ 14(\mathrm{e}), 15$ U.S.C. $\$ 78 \mathrm{n}(\mathrm{e})$ claims fall into this category.

53. See PSLRA, supra note $11, \S 21 \mathrm{D}(\mathrm{g})(10)(\mathrm{A})(\mathrm{i})(\mathrm{II}), 15$ U.S.C. $\S 78 \mathrm{u}-4(\mathrm{~g})(10)$ (A)(i)

(II) (stating that one of the requirements for invocation of the joint and several liability 
tion thus raised is whether a plaintiff must show reasonable reliance on the material misstatement or half-truth in order to bring a defendant within the joint and several liability framework.

The question should be answered generally in the affirmative. The prevailing view is that a plaintiff in a Section 10(b) action must establish reliance as to both misrepresentations and half-truths. ${ }^{54}$ Given the language of the statutory definition and the public policy underlying the 1995 legislation, Congress intended to include this requirement. Nonetheless, this language should have no effect on causes of action predicated on presumptions of reliance under existing Supreme Court precedent, ${ }^{55}$ or under theories predicated on "fraud on the market" 56 or "fraud created the market" 57 for purposes of finding defendants jointly and severally liable. Under such circumstances, absent a clear congressional mandate otherwise, investor reliance should be held to be reasonable as a matter of law.

Although the focus of Title II most frequently implicates actions brought under Section 10(b) of the 1934 Act, the broad language of Title II makes clear that it affects actions brought under all liability provisions of the 1934 Act and actions brought against "outside directors" under Section 11 of the 1933 Act. Thus, the following discussion explores key issues relating to the likely impact of Title II on these provisions.

b. Section 14(a) and Rule 14a-9 Scienter Requirement

In J.I. Case Co. v. Borak, ${ }^{58}$ the Supreme Court recognized an implied private right of action for damages under Section 14(a) ${ }^{59}$ and Rule 14a-9

scheme is that "[p]ersons are likely to reasonably rely on that misrepresentation or omission") (emphasis added)).

54. See cases cited supra note 50.

55. See, e.g., Mills v. Electric Auto-Lite Co., 396 U.S. 375, 385 (1970) (stating that in the $\S 14(\mathrm{a})$ and Rule 14a-9 proxy context, once "there has been a finding of materiality, a shareholder has made a sufficient showing of causal relationship between the violation and the injury for which he seeks redress if ... he proves that the proxy solicitation itself ... was an essential link in the accomplishment of the transaction"). See generally Marc I. Steinberg \& William A. Reece, The Supreme Court, Implied Rights of Action, and Proxy Regulation, 54 Oніо ST. L.J. 67 (1993).

56. See, e.g., Basic, Inc. v. Levinson, 485 U.S. 224, 245-49 (1988). See generally 4 ALAN Bromberg \& Lewis D. Lowenfels, Securities Fraud and Commodities Fraud § 8.6 (1995); Donald C. Langevoort, Theories, Assumptions, and Securities Regulation: Market Efficiency Revisited, 140 U. PA. L. ReV, 851 (1992); John M. Newman, Jr. et al., Basic Truths: The Implications of the Fraud-on-the-Market Theory for Evaluating the "Misleading" and "Materiality" Elements of Securities Fraud Claims, 20 J. CORP. L. 571 (1995).

57. See, e.g., Shores v. Sklar, 647 F.2d 462 (5th Cir. 1981) (en banc) (establishing the fraud-created-the-market theory), cert. denied, 459 U.S. 1102 (1983); Ross v. Bank South, N.A., 885 F.2d 723 (11th Cir. 1989), cert. denied, 495 U.S. 905 (1990); Stinson v. Van Valley Dev. Corp., 719 F. Supp. 362, 366 (E.D. Pa. 1989) (adopting modified version of this theory), aff d, 897 F.2d 524 (3d Cir. 1990). But cf. Eckstein v. Balcor Film Investors, 8 F.3d 1121,1130 (7th Cir. 1993) (renouncing this theory but adopting alternative manner for plaintiff to enjoy presumption of reliance), cert. denied, 510 U.S. 1073 (1994). See generally Julie A. Herzog, Fraud Created the Market: An Unwise and Unwarranted Extension of Section 10(b) and Rule 10b-5, 63 GEO. WASH. L. REV. 359 (1995).

58. 377 U.S. 426 (1964).

59. 15 U.S.C. $\& 78 n(a)(1994)$. 
promulgated thereunder. ${ }^{60}$ Rule $14 \mathrm{a}-9$ prohibits the solicitation of proxies which contain any materially false or misleading statements. ${ }^{61} \mathrm{Re}-$ garding the requisite culpability for liability purposes, Section 14(a), unlike Section 10(b), does not by its terms require that deceptive or manipulative conduct be shown. Based partially on this rationale, most courts apply a negligence standard. ${ }^{62}$ Nonetheless, the joint and several liability scheme underlying the 1995 legislation requires that the culpable party act with actual knowledge to be jointly and severally liable. ${ }^{63}$ Hence, negligence or even recklessness cannot satisfy the actual knowledge standard. ${ }^{64}$ Thus, given the statutory prerequisites of joint and several liability and the current interpretation of actions brought under Section 14(a) and Rule 14a-9 promulgated thereunder, a subject defendant found liable under the proxy regulations whose conduct lacks actual knowledge will henceforth only be proportionately, as opposed to jointly and severally, liable in multidefendant securities actions.

\section{c. Controlling Person Liability Under the 1934 Act}

Section 20(a) of the 1934 Act expressly holds persons and entities falling within the scope of "control persons" liable to the same extent as the persons they control. 65 This Section exculpates a control person only if such control person acted in good faith and did not directly or indirectly induce the act(s) constituting the violation or cause of action. ${ }^{66}$ Frequently the provision is invoked in the broker-dealer and corporation contexts with respect to the liability of supervisors, managers, officers, and directors for the actions of the entity's representatives. ${ }^{67}$ Other than

60. 17 C.F.R. \& 240.14a-9 (1996).

61. See, e.g., Virginia Bankshares, Inc. v. Sandberg, 501 U.S. 1083 (1991).

62. See, e.g., Gould v. American-Hawaiian S.S. Co., 535 F.2d 761, 777-78 (3d Cir. 1976) ("The language of Section 14(a) and Rule 14a-9 contains no suggestion of a scienter requirement, merely establishing a quality standard for proxy material ... [Given all of these factors] the imposition of a standard of due diligence as opposed to actual knowledge or gross negligence is quite appropriate."). Accord, Wilson v. Great Am. Indus., Inc., 855 F.2d 987, 995 (2d Cir. 1988); Shidler v. All Am. Life \& Fin. Corp., 775 F.2d 917, 927 (8th Cir. 1985). But see Adams v. Standard Knitting Mills, Inc., 623 F.2d 422, 428 (6th Cir. 1980 ) (applying scienter standard in $\$ 14(a)$ action against accountants).

63. See PSLRA, supra note $11, \S 21 \mathrm{D}(\mathrm{g})(2)(\mathrm{A}), 21 \mathrm{D}(\mathrm{g})(10)(\mathrm{A}), 15$ U.S.C. $\S 78 \mathrm{u}-$ $4(\mathrm{~g})(2)(\mathrm{A}), 78 \mathrm{u}-4(\mathrm{~g})(10)(\mathrm{A})$.

64. Id. § $21 \mathrm{D}(\mathrm{g})(10)(\mathrm{B}), 15$ U.S.C. $\S 78 \mathrm{u}-4(\mathrm{~g})(10)(\mathrm{B})$.

65. Section 20 (a) reads:

Every person who, directly or indirectly, controls any person liable under any provision of this chapter or of any rule or regulation thereunder shall also be liable jointly and severally with and to the same extent as such controlled person is liable, unless the controlling person acted in good faith and did not directly or indirectly induce the act or acts constituting the violation or cause of action.

15 U.S.C. \& 78t(a) (emphasis added).

66. Id.

67. See, e.g., Hollinger v. Titan Capital Corp., 914 F.2d 1564 (9th Cir. 1990) (en banc); Harrison v. Dean Witter Reynolds, Inc., 974 F.2d 873 (7th Cir. 1992), cert. denied, 509 U.S. 903 (1993); Robbins v. Moore Medical Corp., 788 F. Supp. 179 (S.D.N.Y. 1992); Seidel v. Public Serv. Co., 616 F. Supp. 1342 (D.N.H. 1985). 
the possible survival of liability premised on respondeat superior, ${ }^{68} \mathrm{Sec}-$ tion 20(a) is the remaining Section under the 1934 Act through which secondary liability may be imposed in private actions following the U.S. Supreme Court's elimination of aiding and abetting liability, ${ }^{69}$ and is further the only provision under the 1934 Act which expressly provides for joint and several liability. ${ }^{70}$

Nonetheless, the question arises that, if the "controlled person" is found to be proportionately, as opposed to jointly and severally, liable under the new statutory liability scheme in the PSLRA, to what extent is the control person liable. Under such circumstances, would the control person be deemed a "person claimed by any of the parties to have caused or contributed to the loss incurred" and liable only for its own percentage of responsibility, ${ }^{71}$ thus partially obviating the need for Section 20(a)? If the control person is made a defendant, then by definition it may be construed as a covered person and, absent the requisite culpability for joint and several liability, will thus be liable only for its own percentage of responsibility as determined under the proportionate liability scheme. ${ }^{72}$ On the other hand, it certainly can be asserted that, based on Section 20(a)'s language, the control person's extent of liability is derivative in character and premised on the proportionate fault of its controlled person. Thus, its liability is identical to that of the controlled person (unless the control person meets the statute's affirmative defense). This is clearly a matter of statutory interpretation which awaits judicial clarification.

\section{d. Liability of Outside Directors Under Section 11 of the 1933 Act}

The PSLRA amends Section 11 of the 1933 Act to incorporate special limitation of liability provisions for "outside directors," the definition of which is to be determined by the SEC in future rules or regulations. ${ }^{73}$

68. See discussion supra note 1 .

69. See Central Bank v. First Interstate Bank, 511 U.S. 164 (1994). Hence, persons that may have been liable in private actions under aiding and abetting liability must now be tried as primary violators or under control person or respondeat superior liability. See discussion supra note 1.

70. Section 20(a) provides that unless the control person in question can establish the requisite good faith defense, that person will "be liable jointly and severally with and to the same extent" as the controlled person is liable. 15 U.S.C. $\$ 78 \mathrm{t}(\mathrm{a})$.

71. See PSLRA, supra note $11, \S 21 \mathrm{D}(\mathrm{g})(3)(\mathrm{A}), 15$ U.S.C. $\$ 78 \mathrm{u}-4(\mathrm{~g})(3)(\mathrm{A})$. In other words, would the control person be jointly and severally liable for the amount of damages attributable to the percentage of responsibility assessed against the controlled person?

72. Id. $\& 21 \mathrm{D}(\mathrm{g})(2)(\mathrm{B})(\mathrm{i}), 15$ U.S.C. $\$ 78 \mathrm{u}-4(\mathrm{~g})(2)(\mathrm{B})(\mathrm{i})$.

73. See 15 U.S.C. $\$ 77 \mathrm{k}(\mathrm{f})(2)(\mathrm{A}-\mathrm{B})$. New $\$ 11(\mathrm{f})$ now reads as follows:

(f) Joint and Several Liability (1) Except as provided in paragraph (2), all or any one or more of the persons specified in subsection (a) of this Section shall be jointly and severally liable, and every person who becomes liable to make any payment under this Section may recover contribution as in cases of contract from any person who, if sued separately, would have been liable to make the same payment, unless the person who has become liable was, and the other was not, guilty of fraudulent misrepresentation.

(2)(A) The liability of an outside director under subsection (e) of this section shall be determined in accordance with Section 38 of the Securities Exchange Act of 1934. 
Perhaps the key issue to be resolved in this setting is the meaning of the term "outside director." Certainly, one who serves as a board member with no other significant relationship to the enterprise should be defined as an outside director. Conversely, one who is employed by the enterprise, such as holding the position of executive vice president or inside general counsel, is an inside director. A more difficult dilemma arises with respect to directors who, although not employed by the enterprise, enjoy a significant relationship with that enterprise. This scenario may arise, for example, when a director's law firm serves as outside general counsel or when such director's financial institution supplies key credit for the enterprise. In making this determination of outside director status, the principal criterion should be director independence. Clearly, if one's continued financial well-being depends to a significant degree on placating corporate management, such a director realistically should be defined as neither independent nor outside, and, hence, should not enjoy favored liability status under Section $11 .{ }^{.4}$

\section{Statutory Contribution Mechanisms for Jointly and Severally Liable "Covered" Persons}

As a general proposition, in pre-PSLRA cases, non-settling defendants could assert federal contribution claims ${ }^{75}$ against jointly and severally lia-

(B) For purposes of this paragraph, the term "outside director" shall have

the meaning given such term by rule or regulation of the Commission.

Id. Note that reference to Exchange Act $\S 38$ is erroneous. See Avery, supra note 17, at 364 n.196.

74. See generally Aronson v. Lewis, 473 A.2d 805 (Del. 1984); Shlensky v. South Parkway Bldg. Corp., 166 N.E.2d 793 (Ill. 1960); Miller v. Register \& Tribune Syndicate, 336 N.W.2d 709 (Iowa 1983); Gries Sports Enters., Inc. v. Cleveland Browns Football Co., Inc., 496 N.E.2d 959 (Ohio 1986); American Law Instrtute, Principles of Corporate Gov. ERNANCE: ANALYSIS AND ReCOMMENDATIONS (1994).

75. Contribution is generally based upon the equitable theory that even though a wrongdoer may be liable for damages to an injured party, it should not have to bear the entire amount of damages when others are partly at fault. The law of contribution is complex, but the basic parameters have been set forth by the U.S. Supreme Court as follows:

Typically, a right to contribution is recognized when two or more persons are liable to the same plaintiff for the same injury and one of the joint tortfeasors has paid more than his fair share of the common liability. Recognition of the right reflects the view that when two or more persons share responsibility for a wrong, it is inequitable to require one to pay the entire cost of reparation, and it is sound policy to deter all wrongdoers by reducing the likelihood that any will entirely escape liability.

Northwest Airlines, Inc. v. Transport Workers Union, 451 U.S. 77, 87-88 (1981) (footnotes omitted). Although early common law was opposed to contribution, most states have since adopted contribution rules. See John H. Langmore \& Robert A. Prentice, Contribution Under Section 12 of the Securities Act of 1933: The Existence and Merits of Such a Right, 40 EMORY L.J. 1015, 1058 (1991) (citing statutes). Most commentators have apparently supported the theory that contribution serves as an effective deterrent to potential violators of the securities laws because it reduces the likelihood that any wrongdoer would avoid liability. Id. at 1021. Contribution is a significantly different concept from indemnification: while contribution seeks to apportion or share the loss among two or more joint tortfeasors, indemnification seeks to compel the shifting of the loss from one defendant to another. See Northwest Airlines, Inc., 451 U.S. at 87 n.17; Franklin v. Kaypro Corp., 884 F.2d 1222, 1226-27 (9th Cir. 1987). See also Liberti, supra note 13, at 64; Dianne M. Han- 
ble settling defendants under Section 11 of the 1933 Act $^{76}$ and Section 10(b) of the 1934 Act. ${ }^{77}$ First, Section 11(f) provides for an express statutory right to contribution against another party liable under Section 11 "unless the person who has become liable was, and the other was not, guilty of fraudulent misrepresentation."78 Second, in Musick, Peeler \&

sen, The Effect of Partial Settlements on the Rights of Non-Settling Defendants in Federal Securities Class Actions: In Search of a Standardized Uniform Contribution Bar Rule, 60 UMKC L. REv. 91, 94 \& n.17 (1991).

76. The existence of an implied right to contribution under $\$ 12(2)$ (now $\S 12(a)(2)$ ) of the 1933 Act, however, is in doubt. First, $\$ 12$ does not contain any express terms providing for contribution among wrongdoers. Second, while several early decisions apparently recognized a right to contribution under $\S 12(2)$, the more recent decisions have all refused to imply a right to contribution under $\$ 12(2)$. For cases holding that a right to contribution exists under $\$ 12(2)$ (or $\$ 12(a)(2)$ ), see, e.g., Getter v. R.G. Dickinson \& Co., Inc., 366 F. Supp. 559, 568-69 (S.D. Iowa 1973); Nelson v. Quimby Island Reclamation Dist., 491 F. Supp. 1364, 1383 (N.D. Cal. 1980); Odette v. Shearson, Hammill \& Co., 394 F. Supp. 946, 957-58 (S.D.N.Y. 1975). See also Langmore \& Prentice, supra note 75, at 1058 (arguing in favor of right to contribution under $\S 12$ ). For cases holding no such right to contribution exists, see, e.g., Baker, Watts \& Co. v. Miles \& Stockbridge, 876 F.2d 1101, 1105-06 (4th Cir. 1989); In re Citisource, Inc. Sec. Litig., 694 F. Supp. 1069, 1083 (S.D.N.Y. 1988); In re Professional Fin. Management, Ltd., 683 F. Supp. 1283, 1286 (D. Minn. 1988); DeltajHoldings v. National Distillers \& Chem. Corp., [1985-1986 Transfer Binder] Fed. Sec. L. Rep. (CCH) II 92,910 (S.D.N.Y. 1986). See also In re Del-Val Fin. Corp. Sec. Litig., 868 F. Supp. 547,553 n.7 (S.D.N.Y. 1994) (declining to address the issue).

The U.S. Supreme Court has previously recognized this question, but declined to address it. See Pinter v. Dahl, 486 U.S. 622,630 n.9 (1988). Since the Supreme Court's decision in Pinter, courts have declined to imply a right to contribution under $\S 12(\mathrm{a})(2)$. Langmore \& Prentice, supra note 75, at 1031.

The analysis of statutory interpretation of the federal securities laws by the U.S. Supreme Court in Musick, Peeler \& Garrett v. Employers Ins., 508 U.S. 286 (1993) and several more recent securities decisions have in all likelihood closed the door on this question. See, e.g., Gustafson v. Alloyd Co., 115 S. Ct. 1061 (1995); Central Bank, 511 U.S. at 164.

On the other hand, insofar as the right to contribution is concerned, in the unregistered public offering context, $\$ 12(2)$ (or now $\$ 12(a)(2)$ ) may arguably be viewed as the counterpart to $\$ 11$, which expressly provides for contribution in subsection (f). Hence, because the provisions should arguably be construed consistently, it may be asserted that the courts should imply a right to contribution under $\$ 12(2)$. See STEINBERo, supra note 42, $\$ 6.02[4]$. If this argument is unsustainable, however, non-settling defendants would probably not be able to maintain claims for contribution under $\$ 12(2)(\S 12(\mathrm{a})(2))$ of the 1933 Act.

In addition, it is unclear as to whether entities or individuals found to be "control persons" either under (i) $\S 15$ of the 1933 Act for their agents' or employees' violations of $\S \S 11$ and 12, or (ii) $\S 20$ (a) of the 1934 Act for the same persons' violations of $\S 10$ (b) and Rule 10b-5 or other Exchange Act provisions have contribution rights under the federal securities laws. See discussion supra notes 65-72 and accompanying text.

77. See infra notes $79-83$ and accompanying text.

78. 15 U.S.C. $\$ 77 \mathrm{k}(\mathrm{f})$. Section $11(\mathrm{f})$ provides:

All of any one or more of the persons specified in subsection (a) of this section shall be jointly and severally liable, and every person who becomes liable to make any payment under this section may recover contribution as in cases of contract from any person who, if sued separately, would have been liable to make the same payment, unless the person who has become liable was, and the other was not, guilty of fraudulent misrepresentation.

ld. (emphasis added). See Eichenholtz v. Brennan, 52 F.3d 478, 483 (3d Cir. 1995); In re Jiffy Lube Sec. Litig., 927 F.2d 155, 160 (4th Cir. 1991); Kaypro Corp., 884 F.2d at 1226-27 \& nn. 3-4 (all describing basis and legislative history of $\$ 11(\mathrm{f})$ ). See also In re Del-Val Fin. Corp. Sec. Litig., 868 F. Supp. at 553 n.7; TBG, Inc. v. Bendis, 811 F. Supp. 596, 601 n.6 (D. Kan. 1992), rev'd and remanded on other grounds, 36 F.3d 916 (10th Cir. 1994); In re Crazy 
Garrett v. Employers Insurance ${ }^{79}$ the U.S. Supreme Court recognized an implied right to contribution under Section 10(b) and Rule 10b-5. In $\mathrm{Mu}$ sick, the Supreme Court focused its inquiry not on whether contribution was more or less efficient or equitable, but rather as to "how the 1934 Congress would have addressed the issue had the [Section 10(b)] action been included as an express provision in the 1934 Act." 80 The Court initially observed that as Congress had made no attempt to define the contours of the private cause of action under Section 10(b), "Congress had no occasion to address how to limit, compute or allocate liability arising from it." 81 Hence, the Musick Court premised its holding on the proposition that of the eight liability provisions contained in the 1933 and 1934 Acts, Exchange Act Sections 9 and 18 imposed liability upon defendants who stand in a position "most similar to 10b-5 defendants" for assessing whether they should be entitled to contribution. ${ }^{82}$ Thus, as Sections 9 and 18 contain nearly identical express provisions granting rights to contribution, the Supreme Court held that an implied right to contribution in Section $10(b)$ actions was proper. ${ }^{83}$

Eddie Sec. Litig., 740 F. Supp. 149, $152-53$ (E.D.N.Y. 1990); Alvarado Partners, L.P. v. Mehta, 723 F. Supp. 540, 550 (D. Colo. 1989), appeal dism'd as moot, 936 F.2d 582 (10th Cir. 1991) (all confirming statutory right to contribution under $\S 11(\mathrm{f})$ ).

79. 508 U.S. 286 (1993). Although Musick conclusively settled the issue whether liability in Rule 10b-5 litigation is accompanied by a right to contribution, almost every other court to consider the issue had previously implied a right to contribution under Rule 10b-5. See James J. Hagan \& Joseph M. McLaughlin, Fairness in the Balance: The Use of Bar Orders and Judgment Reduction in the Settlement of Multi-Defendant Securities Litigation, 1 StAN. J.L. Bus. \& Fin. 29, 30 \& n.4 (1994) (citing cases).

80. Musick, 508 U.S. at 294.

81. Id. at 295.

82. Id.

83. Id. at 297. Although the Supreme Court did not explicitly identify the elements necessary to state a cause of action for contribution under $\S 10(\mathrm{~b})$, it did indicate that liability for contribution was typically identical to liability for the original claim. Id. Hence, the liability of a potential contributor is based upon its liability to the plaintiff, rather than for the wrongs committed only among defendants. Thus, under Musick, the first element is essentially the same for all contribution claims. It simply requires that the person from whom contribution is sought, if joined in the original suit, would have been liable to make the same payment. For example, several cases in the Second Circuit have required that the third-party complaint allege each element of the original claim. See, e.g., Ades v. Deloitte \& Touche, 843 F. Supp. 888, 893 (S.D.N.Y. 1994); Department of Econ. Dev. v. Arthur Andersen \& Co., 747 F. Supp. 922, 934 (S.D.N.Y. 1990).

The second element requires that a right of contribution exist between those who share joint liability. See, e.g., Stratton Group, Ltd. v. Sprayregen, 466 F. Supp. 1180, 1185 n.6 (S.D.N.Y. 1979):

The term "joint tortfeasors" means that two or more persons are the joint participants or joint actors in the wrongful production of an injury to a third person.... [T] he act of each is his own act but the acts are concurrent and, or contribute to, the production of the wrongful injury, so that each actor is, on his own account, liable for the resulting damages.

Hence, the current standard for contribution under $\S 10(b)$ requires that the defendant, such as an accounting firm, with scienter participated in the fraud against the plaintiffs in question. See, e.g., Advanced Magnetics, Inc. v. Bayfront Partners, No. 92 Civ. 6879, 1993 U.S. Dist. LEXIS 16152 , at *16 (S.D.N.Y. Nov. 12, 1993). Thus, in combining these elements, all that is required are "allegations that the defendant and third-party [defendant] were joint participants in the fraud alleged by the plaintiffs." Greene v. Emersons, Ltd., 102 F.R.D. 33, 36 (S.D.N.Y. 1983), aff'd, 736 F.2d 29 (2d Cir. 1984). 
Nonetheless, the Supreme Court left several questions unresolved in Musick, including: (i) the extent of the non-settling defendants' contribution and indemnification ${ }^{84}$ rights in partial settlements (for instance, whether or not the right to contribution is calculated according to relative

See also, Employers Ins. v. Musick, Peeler \& Garrett, 954 F.2d 575, 579 (9th Cir. 1992), aff d, 508 U.S. 286 (1993). On remand from the Supreme Court, the insurance companies in Musick amended the complaint to allege that the attorneys and accountants were primary violators of the federal securities laws, in light of the Supreme Court's decision in Central Bank, 511 U.S. at 164. The defendants argued that after the narrow construction of $\S 10$ (b) by the Supreme Court in Central Bank, the district court should not imply a right of contribution by an insurer who is subrogated to a right of contribution. Rather, the defendants contended that the right of contribution approved by the Supreme Court in $\mathbf{M u}$ sick should apply only to defendants in an action who themselves sought contribution from joint tortfeasors. $871 \mathrm{~F}$. Supp. at 384-85. The district court rejected this argument, however, and held that in the case of contribution actions brought by an insurer rather than the original joint tortfeasor, only a theory of recovery, as opposed to a theory of liability, was at issue. Id. at 385 . Hence, as the Central Bank opinion addressed implied theories of liability, and not theories of recovery, the district court allowed the insurance companies to pursue their contribution action as subrogees. Id.

84. Although the Musick decision conclusively settled the question of whether contribution exists as an implied private right in Rule 10b-5 litigation, it did not address whether an implied right to indemnification exists under $\S 10(\mathrm{~b})$ or Rule $10 \mathrm{~b}-5$. The vast majority of courts, however, have held that the policy implications of joint and several liability preclude recognition of an implied right to indemnification both in general under the federal securities laws and specifically under $\$ 10(\mathrm{~b})$ and Rule 10b-5. See, e.g., Eichenholtz, 52 F.3d at 483-84 (citing cases); In re U.S. Oil \& Gas Litig., 967 F.2d 489, 495 (11th Cir. 1992); First Golden Bancorporation v. Weiszmann, 942 F.2d 726, 728 (10th Cir. 1991); Riverhead Sav. Bank v. National Mortgage Equity Corp., 893 F.2d 1109, 1116 (9th Cir. 1990); Stewart v. American Int'l Oil \& Gas Litig., 845 F.2d 196, 200 (9th Cir. 1988); Laventhol, Krekstein, Horwath \& Horwath v. Horwitch, 637 F.2d 672, 676 (9th Cir. 1980); Heizer Corp. v. Ross, 601 F.2d 330, 334 (7th Cir. 1979); Globus v. Law Research Serv. Inc., 418 F.2d 1276, 128889 (2d Cir. 1969), cert. denied, 397 U.S. 913 (1970); Department of Economic Dev. v. Arthur Andersen \& Co., 747 F. Supp. 922, 931 (S.D.N.Y. 1990) (all holding that indemnification is generally unavailable under the federal securities laws because a securities wrongdoer cannot escape loss by shifting its entire responsibilities for joint and several liability to another party under indemnification principles). $C f$. King v. Gibbs, 876 F.2d $1275,1280-81$ (7th Cir. 1989) (declining to recognize indemnification under the federal securities laws due to lack of congressional intent to create such a right).

Similarly, courts have refused to recognize a right to indemnification under $\S \S 11$ and 12(2). Moreover, courts have invalidated claims for contractual indemnification premised upon indemnification clauses in underwriting agreements between underwriters and issuers on similar grounds. See, e.g., Eichenholtz, 52 F.3d at 484-85 \& nn. 11, 12 (holding that underwriter indemnification agreements are counter to the policies underlying the federal securities laws); Kaypro Corp., 884 F.2d at 1232 (contractual indemnification clauses are invalid because they are against the policy of $\S 11(\mathrm{f})$ ); Stewart, 845 F.2d at 200 (contractual indemnification clauses are invalid because they are against the policy of $\$ 11(\mathrm{f})$ ); Baker, Watts \& Co. v. Miles \& Stockbridge, 876 F.2d 1101, 1104-05 (4th Cir. 1989) (no implied right to indemnification exists under $\$ 12(2)$ ); In re Wilshire Technology Sec. Litig., $887 \mathrm{~F}$. Supp. 236, 239-40 (S.D. Cal. 1995) (all indemnity agreements are invalid under the federal securities laws); Alvarado Partmers, L.P., 723 F. Supp. at 549 (no expressed or implied right to indemnification exists under $\S 11)$; In re Professional Management, Ltd., 683 F. Supp. at 1285 (no implied right to indemnification exists under $\$ 12(2)$ ).

In instances where an underwriter is found vicariously liable for the actions of its nonsettling agents, however, the Third Circuit has recognized that in partial settlements the underwriter may maintain an action for indemnification against the agent without running afoul of the securities laws. See Eichenholtz, 52 F.3d at 485 \& n.13; Sharp v. Coopers \& Lybrand, 649 F.2d 175, 181-82 (3d Cir. 1981), cert. denied, 455 U.S. 938 (1982); In re Olympia Brewing Co. Sec. Litig., 674 F. Supp. 597, 613-14 (N.D. Ill. 1987) (all addressing vicarious liability between underwriter and agent). 
fault); (ii) whether federal contribution rights can be precluded by settlement bar orders used by settling defendants to prevent non-settling defendants from bringing contribution actions against them; and (iii) the extent of the settling defendants' rights, if any, to bring contribution actions against the non-settling defendants. ${ }^{85}$

The PSLRA preserves the right of jointly and severally liable defendants to seek contribution from one another. As discussed later, ${ }^{86}$ the 1995 legislation addresses each of the questions left open in Musick. All covered persons who become jointly and severally liable for damages in any private action within the PSLRA liability scheme may recover contribution from any other person who, if joined in the original action, would have been liable for the same damages. ${ }^{87}$ The 1995 legislation provides that such a claim for contribution shall be determined based on the percentage of responsibility of the claimant and of each person against whom a claim for contribution is made. ${ }^{88}$ The PSLRA also provides, however, for a specifically delineated statute of limitations for contribution actions. In particular, in any private action determining liability, an action for contribution must be brought no later than six months after the entry of a final, nonappealable judgment in the action. ${ }^{89}$

\section{B. The New Proportionate Liability Framework}

Securities fraud cases often involve multiple defendants with differing degrees of involvement in, and responsibility for, the alleged fraudulent conduct. In order to mitigate the perceived unfairness imposed upon lesser culpable defendants under the liability framework, the PSLRA provides for the apportionment of liability among co-defendants on the basis of relative fault.90 The PSLRA establishes a proportionate liability

85. In Musick, the party attempting to bring contribution actions was an insurance company acting as the insureds' subrogees seeking to sue attorneys and accountants involved in the public offering. See Musick, 954 F.2d at 577. Hence, as the question before the Supreme Court was narrowly limited to whether an implied private right of contribution existed under $\S 10(\mathrm{~b})$ and Rule $10 \mathrm{~b}-5$ at all, the Court did not address the factual posture of the case. Musick, 508 U.S. at 288. Notably, however, the Ninth Circuit expressly held that a settlement agreement could not be relied upon to preclude "subsequent actions for contribution by settling defendants against individuals who were not party to the original suit." Musick, 954 F.2d at 579. Such narrow language would not per se authorize contribution actions by settling defendants against non-settling defendants who are parties to the original suit in this instance. However, the settling defendant's right to contribution against non-settling defendants was considered and upheld in In re Del-Val Fin. Corp. Sec. Litig., 868 F. Supp. 547 (S.D.N.Y. 1994), discussed infra notes 170-82 and accompanying text.

86. See infra notes $95-104,183-96$ and accompanying text.

87. PSLRA, supra note $11, \S 21 \mathrm{D}(\mathrm{g})(8), 15$ U.S.C. $\$ 78 \mathrm{u}-4(\mathrm{~g})(8)$.

88. Id.

89. Id. $\$ 21 \mathrm{D}(\mathrm{g})(9), 15$ U.S.C. $\$ 78 \mathrm{u}-4(\mathrm{~g})(9)$.

90. This standard thus codifies the position taken by the Ninth Circuit in Kaypro Corp., the Supreme Court in McDermott Inc. v. AmClyde, 511 U.S. 202 (1994), and the Tenth Circuit majority and Justice White's concurring opinion in TBG, Inc. v. Bendis, 36 F.3d 916, 929-39 (10th Cir. 1994), all of which are discussed infra notes 137-69 and accompanying text. For example, in $T B G$, Inc., Justice White concluded in his concurring opinion that the settlement agreement in question had to be rejected in large part because the pro 
regimen for all covered persons that have not "knowingly committed a violation of the securities laws." 91 In particular, the Litigation Reform Act provides that a covered person against whom a final judgment is entered in a private action shall be liable solely for the portion of the judgment that corresponds to the percentage of responsibility of that covered person. .92

The PSLRA also delineates a specific procedure for the factfinder's determination of responsibility in the proportionate liability framework. In any private action, the court is directed to instruct the jury to answer special interrogatories (or if there is no jury, the court is to make such findings) with respect to each covered person and each of the other persons claimed by any of the parties to have caused or contributed to the loss incurred by the plaintiff(s), including persons who have entered into settlement with the plaintiff(s) concerning: "(i) whether such person violated the securities laws; (ii) the percentage of responsibility of such person, measured as a percentage of the total fault of all persons who caused or contributed to the loss incurred by the plaintiff; and (iii) whether such person knowingly committed a violation of the securities laws."93 The PSLRA provides that the responses to interrogatories or findings made must specify the total amount of damages that the plaintiff is entitled to recover and the percentage of responsibility of each covered person found to have caused or contributed to the loss incurred by the plaintiff(s). ${ }^{94}$

tanto method coupled with a bar order created an inconsistency with the non-settling defendants' relative fault contribution rights and that the proportionate fault method created no such inconsistencies with the $\S 10$ (b) right. See TBG, Inc., 36 F.3d at 937 (White, J., sitting by designation, concurring in part and concurring in judgment). The critical premise to these conclusions was that the $\S 10$ (b) contribution right was indeed calculated according to relative fault. Id.

The Senate Report to the Litigation Reform Act asserted that the proportionate liability scheme was broadly supported by almost all witnesses, and in particular the SEC was a strong supporter of proportionate liability. In addition, SEC Chairman Arthur Levitt testified numerous times on behalf of the SEC in this regard. See Litigation Reform Proposals Before the Subcomm. on Sec. of the Senate Comm. on Banking, Housing and Urban Affairs, 104th Cong. (1995) (testimony of Arthur Levitt, Chairman of the SEC) [hereinafter Testimony of Arthur Levitt]. Finally, former SEC Commissioner J. Carter Beese, Jr., specifically urged that Congress enact both a joint and several liability scheme for primary tortfeasors and apportion liability according to relative fault for defendants who have not "knowingly participated" in the fraud. See Testimony of J. Carter Beese, Jr., supra note 36.

Nonetheless, it is worth noting that after the McDermott decision at least one federal circuit court declined to extend the proportionate fault rule in the CERCLA context. See, e.g., Azko Coatings, Inc. v. Aigner Corp., 30 F.3d 761, 769 (7th Cir. 1994) (holding that the proportionate fault rule was inapplicable in a CERCLA action because it was incompatible with the unique statutory liability scheme).

91. PSLRA, supra note 11 , \& $21 \mathrm{D}(\mathrm{g})(2)(\mathrm{A}), 15$ U.S.C. $\& 78 \mathrm{u}-4(\mathrm{~g})(2)(\mathrm{A})$.

92. Id. $\$ 21 \mathrm{D}(\mathrm{g})(2)(\mathrm{B})(\mathrm{i}), 15$ U.S.C. $\& 78 \mathrm{u}-4(\mathrm{~g})(2)(\mathrm{B})(\mathrm{i})$. Subparagraph (B)(ii) states that "[i]n any case in which a contractual relationship permits, a covered person that prevails in any private action may recover the attorney's fees and costs of that covered person in connection with the action." Id. $\$ 21(\mathrm{D})(\mathrm{g})(2)(\mathrm{B})(\mathrm{ii}), 15$ U.S.C. $\S 78 \mathrm{u}-4(\mathrm{~g})(2)(\mathrm{B})$ (ii) (emphasis added).

93. Id. \& $21 \mathrm{D}(\mathrm{g})(3)(\mathrm{A})(\mathrm{i}-\mathrm{iii}), 15$ U.S.C. $\S 78 \mathrm{u}-4(\mathrm{~g})(3)(\mathrm{A})(\mathrm{i}-\mathrm{iii})$.

94. Id. $\$ 21 \mathrm{D}(\mathrm{g})(3)(\mathrm{B}), 15$ U.S.C. $\$ 78 \mathrm{u}-4(\mathrm{~g})(3)(\mathrm{B})$. In determining the percentage of responsibility of the covered person in question, the PSLRA further provides that the trier 


\section{Statutory Authority for the Issuance of Settlement Bar Orders: Closing the Gaps in Partial SetTrlements}

Title II of the PSLRA brings finality to many of the controversial aspects of partial settlements and implements judgment reduction methods in multidefendant securities litigation. The PSLRA eliminates the debatable questions of whether federal courts have the authority ${ }^{95}$ and jurisdic-

of fact is to consider "the nature of the conduct of each covered person found to have caused or contributed to the loss incurred by the plaintiff or plaintiffs; and the nature and extent of the causal relationship between the conduct of each such person and the damages incurred by the plaintiff or plaintiffs." Id. $\$ 21 \mathrm{D}(\mathrm{g})(3)(\mathrm{C})(\mathrm{i})-(\mathrm{ii}), 15$ U.S.C. $\$ 78 \mathrm{u}-$ $4(\mathrm{~g})(3)(\mathrm{C})(\mathrm{i})$-(ii). As with the joint and several liability scheme, the PSLRA provides that the procedure for allocation of damages under the proportionate liability scheme is "not to be disclosed to members of the jury." Id. $\$ 21 \mathrm{D}(\mathrm{g})(6), 15$ U.S.C. $\$ 78 \mathrm{u}-4(\mathrm{~g})(6)$. Note that much of the language setting forth PSLRA's provisions herein quote such provisions.

95. Undoubtedly, abundant federal precedent exists in favor of adopting settlement bar orders in Rule 10b-5 litigation. See, e.g., Eichenholtz, 52 F.3d at 486 (citing cases); In re Masters Mates \& Pilot Pension Plan, 957 F.2d 1020, 1028-30 (2d Cir. 1992); In re Jiffy Lube Sec. Litig., 927 F.2d at 160 n.2; Kaypro Corp., 884 F.2d at 1229-30 \& nn.10-11; Huddleston, 640 F.2d at 559; In re Del-Val Fin. Corp. Sec. Litig., 868 F. Supp. at 556 n.12; Biben v. Card, No. 84-0844-CV-W-6, 1991 U.S. Dist. LEXIS 18448, at *1, *8 (W.D. Mo. Dec. 10, 1991); Vigil v. Finesod, 779 F. Supp. 522, 525 (D.N.M. 1990); MFS Mun. Income Trust v. American Medical Int'l, 751 F. Supp. 279, 281 (D. Mass. 1990); South Carolina Nat'l Bank v. Stone (Stone I), 749 F. Supp. 1419, 1430-31 (D.S.C. 1990) (all observing that federal courts have, almost without exception, approved bar orders precluding claims by non-settling defendants against settling defendants in connection with both federal and state securities law claims). See also Alvarado Partners, L.P., 723 F. Supp. at 548, 551 (holding that implied contribution bar rule exists under $\S 11$ and Rule 10b-5); In re Atlantic Fin. Management, Inc. Sec. Litig., 718 F. Supp. 1012, 1016 (D. Mass. 1988); In re Sunrise Sec. Litig., 698 F. Supp. 1256, 1257-58 \& n.3, 1261 (E.D. Pa. 1988); Nelson v. Bennett, 662 F. Supp. 1324, 1329-32, 1336-38 (E.D. Cal. 1987); In re NuCorp Energy Sec. Litig., 661 F. Supp. 1403, 1408 (S.D. Cal. 1987).

No federal statute, including either the 1933 or 1934 Act, however, expressly authorizes the issuance of settlement bar orders in partial settlements, although at least one court has premised jurisdiction on a procedural statute. In $T B G$, Inc., the Tenth Circuit majority asserted that the power to issue settlement bar orders existed under the All Writs Act, 28 U.S.C. $\$ 1651$ (a) (1994). The All Writs Act authorizes federal courts to "issue all writs necessary or appropriate in aid of their respective jurisdictions." TBG, Inc., 36 F.3d at 925 (citing Washington Public Power Supply Sys. Sec. Litig., 720 F. Supp. 1379, 1399 (D. Ariz. 1989), aff'd sub nom. Class Plaintiffs v. City of Seattle, 955 F.2d 1268 (9th Cir. 1992), cert. denied sub nom. Hoffer v. City of Seattle, 506 U.S. 953 (1992)). As the Tenth Circuit in $T B G$, Inc. recognized, the authority to issue bar orders includes enjoining further suits that serve to relitigate issues a court has already decided. $T B G, \ln c$., 36 F.3d at 925 (citing In re March, 988 F.2d 498, 500 (4th Cir.) ("The All Writs Act empowers a federal court to enjoin parties before it from attempting to relitigate decided issues and to prevent collateral attack of its judgments."), cert. denied, 510 U.S. 864 (1993)). For example, in TBG, Inc., the Tenth Circuit majority asserted that the interest in promoting settlements alone could not represent authority for the imposition of bar orders, but if a court or jury decided the settling defendants' relative fault and somehow credited that amount to the non-settling defendants, "the All Writs Act probably would authorize" a bar order because the parties would otherwise have to relitigate the relative fault issues. TBG, Inc., 36 F.3d at 926 .

The vast majority of courts upholding the issuance of bar orders premised their support either on other federal court precedent or the policy interests of encouraging settlement or judicial economy. Aside from the All Writs Act inquiry, however, the policy interests in promoting settlements and judicial economy may not be sufficient bases of authority for the issuance of bar orders. The argument proceeds as follows. In light of the Musick decision, it is initially questionable whether the federal right to contribution, although related to an implied cause of action, is statutory under $\S 10(\mathrm{~b})$ or merely exists as an equitable remedy. See Musick, 508 U.S. at 294-98. The Supreme Court evidently did not create a 
tion ${ }^{96}$ to issue bar orders in multidefendant securities actions by specifically providing for the implementation of settlement bar orders in

federal common law contribution right in Musick, and although the Court did not explicitly state that this right was statutory, it did not consider the equity or policy arguments in support of establishing this contribution right either. Thus, courts cannot be entirely certain that equity or policy reasons justify modifying or extinguishing the right to contribution through the use of bar orders. In TBG, Inc., however, the Tenth Circuit majority found that the federal right to contribution in Rule $10 \mathrm{~b}-5$ actions was statutory and therefore that courts lacked the power to bar that right for equity or policy reasons, such as the interest in promoting settlements. See TBG, Inc., 36 F.3d at 923-24. Cf. Kaypro Corp., 884 F.2d at 1229 (reasoning that as no statutory provision or prior decisions directly precluded the imposition of bar orders prior to trial, the public interest in settlements permits bar orders). Justice White agreed with this as a general proposition in his concurring opinion in $T B G$, Inc., 36 F.3d at 932 (White, J., sitting by designation, concurring in part and concurring in judgment).

Beyond this line of argument other factors could militate against the issuance of bar orders in pre-PSLRA cases. First, the line between statutory interpretation and judicial lawmaking is quite narrow, and a court may be uncertain as to whether gap filling by courts in this context would be upheld on appeal. See Stuart C. Plunkett, Comment, Courts Lack the Power to Issue Contribution Bar Orders in Securities 10b-5 Cases, 89 Nw. U. L. REv. 1117, 1136-39 (1995) (arguing that Rule 10b-5 cannot reasonably be interpreted to authorize bar orders). Second, it would be difficult to draw support from the legislative intent of Rule 10b-5 to authorize bar orders. Id. at 1139-43. Plunkett observed that the Kaypro Corp. court attempted to base its decision authorizing bar orders on legislative intent:

In Kaypro, the court considered the option of not issuing a contribution bar order, [but] rejected the non-settling defendants' argument that the court could not divest them of a statutorily vested right, stating that "there is nothing in either the statute or our prior decisions that says contribution cannot be satisfied prior to a full trial."

Id. at 1141 (citing Kaypro Corp., 884 F.2d at 1229) (footnotes omitted). Third, some courts have recognized the private alternatives of having the plaintiffs indemnify settling defendants against claims by non-settling defendants that are based on their liability to the plaintiffs, and/or to agree to defend the settling defendants so that the settling defendants do not face more litigation expenses. These indemnification alternatives arguably can be just as effective as bar orders. See, e.g., McDermott, 511 U.S. at 212; TBG, Inc., 36 F.3d at 924; In re Boesky Sec. Litig., 948 F.2d at 1362; In re Del-Val Fin. Corp. Sec. Litig., 868 F. Supp. at 559.

96. In $T B G$, Inc., the Tenth Circuit majority stated without ruling on the question that a court could not have jurisdiction to issue a bar order until the non-settling defendants properly filed their contribution claims against the settling defendants. 36 F.3d at 927 . In particular, the majority asserted that:

The All Writs Act only authorizes such orders in aid of the court's jurisdiction. 28 USC $\S 1651$ (a). It does not authorize a court to assume jurisdiction over claims not otherwise before it. A court therefore cannot bar further contribution claims if it does not have jurisdiction to decide the defendants' proportional fault in the first place. The district court may not have had jurisdiction to decide Shook's contribution liability, especially since the nonsettling defendants had not filed cross-claims for contribution. We doubt that the potential contribution defendant's request to have the court decide its contribution liability could give the court jurisdiction to effectively decide an unwilling potential contribution plaintiff's claim.

Id. at 926-27. (citation omitted) (emphasis added). It is notable that, on remand, the district court agreed with the $T B G$, Inc. majority that courts do not have jurisdiction to select a judgment reduction method until contribution and indemnity actions have been filed by non-settling defendants against settling defendants. See TBG, Inc. v. Bendis, 160 F.R.D. 621,623 (D. Kan. 1995) (on remand from the Tenth Circuit). Justice White, however, found it troubling that the majority would even (i) question the power of the district court to carry out a settlement agreement conditioned upon use of the proportionate fault method, or (ii) similarly provide for a proportionate fault judgment reduction conditioned on the entry of a bar order, although this would be unnecessary for purposes of precluding 
partial settlements in 1934 Act actions. ${ }^{97}$

Comprehensive settlement bar orders seek to preclude all future claims by non-settling defendants and nonparties with an interest in the litigation (including insurance companies representing non-settling defendants responsible for payment of judgments entered up to policy limits) ${ }^{98}$ for contribution and indemnity, however denominated, ${ }^{99}$ against the settling defendants. ${ }^{100}$ The issuance of such bar orders is precisely what gives rise to the need for the implementation of judgment reduction methods to compensate the non-settling defendants for the loss of their rights to pursue such actions against the settling defendants. In pre-PSLRA cases, a number of courts recognized that the failure to obtain these protections would result in additional litigation and thus invite disaster to the settlement. ${ }^{101}$

contribution claims. See TBG, Inc., 36 F.3d at 933-36 (White, J. sitting by designation, concurring in part and concurring in the judgment).

97. See PSLRA, supra note $11, \$ 21 \mathrm{D}(\mathrm{g})(7), 15$ U.S.C. $\$ 78 \mathrm{u}-4(\mathrm{~g})(7)$.

98. See Musick, 508 U.S. at 287-90; In re Del-Val Fin. Corp. Sec. Litig., 868 F. Supp. at 554 (insurers as equitable subrogees have right to contribution in $10 \mathrm{~b}-5$ liability claims). The contribution right is frequently invoked in situations involving director and officer liability for alleged securities fraud. See, e.g., Nordstrom, Inc. v. Chubb \& Son, Inc., 54 F.3d 1424 (9th Cir. 1995); Caterpillar, Inc. v. Great Am. Ins. Co., 62 F.3d 955 (7th Cir. 1995) (D\&O/securities fraud settlement cases); In re Masters Mates, 957 F.2d at 1020, 1024 (insurance policy covering professional liability); Pepsico, Inc. v. Continental Casualty Co., 640 F. Supp. 656, 660-62 (S.D.N.Y. 1986) (insurance policy covering professional liability). The insurance companies usually assume control of the defense of their insureds and preserve their rights to pursue claims against their insureds or other culpable parties, however, they may instead prefer to specifically tailor the provisions of settlement agreements to require their consent to settle above or below specific amounts based on policy limits. See, e.g., Eichenholtz, 52 F.3d at 479-82.

99. In pre-PSLRA cases, the issuance of an enforceable bar order precluding claims for "contribution and indemnity" will normally result in the elimination of all non-settling defendant contribution and indemnification claims under the federal securities laws against settling defendants, to the extent that they are otherwise permissible. See, e.g., In re US Oil \& Gas Litig., 967 F.2d at 489, 495-96; In re Masters Mates, 957 F.2d at 1032; USF\&G Co., 788 F. Supp. at $882-83$ (all holding that bar order against contribution claims extended to eliminate indemnity claims).

100. See, e.g., Eichenholtz, 52 F.3d at 480-81; In re Consolidated Pinnacle West Sec. Litig., 51 F.3d 194, 195 (9th Cir. 1995), cert. denied sub nom. Rice v. FDIC, 116 S. Ct. 771 (1996); TBG, Inc., 36 F.3d at 922-23; In re US Oil \& Gas Litig., 967 F.2d at 491-93; In re Masters Mates, 957 F.2d at 1024; In re Boesky Sec. Litig., 948 F.2d at 1362; Kaypro Corp., 884 F.2d at 1225; In re Wilshire Sec. Litig., 887 F. Supp. at 237-39; Scholes v. Stone, McGuire \& Benjamin, 839 F. Supp. 1314, 1318-20 (N.D. Ill. 1993), aff'd sub nom. Scholes v. Lehmann, 56 F.3d 750 (7th Cir. 1995); Cortec Indus., Inc. v. Sum Holdings L.P., 839 F. Supp. 1021, 1023 (S.D.N.Y. 1993); In re Meldridge, Inc. Sec. Litig., 837 F. Supp. 1076, 1077 (D. Ore. 1993); In re Granada Partnership Sec. Litig., 803 F. Supp. 1236, 1238 (S.D. Tex. 1992); In re VMS Ltd. Partnership Sec. Litig., 803 F. Supp. 179, 182 \& n.1 (N.D. Ill 1992); Biben, 1991 U.S. Dist. LEXIS 18448, at *7-8; Vigil, 779 F. Supp. at 523. See also USF\&G Co. v. Patriot's Point Dev. Auth., 772 F. Supp. 1565, 1567-68 (D.S.C. 1991) (complex securities litigation involving multiple settlement agreements, all of which were conditioned in different respects regarding selection of judgment reduction method and barring of claims beyond contribution); South Carolina Nat'l Bank (Stone I), 749 F. Supp. at 1423 (barring assertion of all cross-claims "arising out of" the case); Dalton v. Alston \& Bird, $741 \mathrm{~F}$. Supp. 157, 158 (S.D. Ill. 1990) (barring assertion of all cross-claims against settling defendants).

101. See, e.g., In re NuCorp Energy Sec. Litig., 661 F. Supp. 1403, 1408 (S.D. Cal. 1987). Counsel for settling defendants would also recognize, however, that even if bar orders are 
approved and imposed, courts generally would in the interests of equity, fairness, and promotion of settlements, attempt to ensure that any judgments obtained against the nonsettling defendants would be offset or reduced by a specific judgment reduction method. This would be effectuated in order to compensate non-settling defendants for the loss of their rights to pursue such claims, and to prevent the plaintiffs from obtaining an inequitable double-recovery windfall in the process.

The question of which judgment reduction method courts should adopt in pre-PSLRA multidefendant securities actions or in actions not within the scope of the 1995 legislation, however, remains an unsettled issue. Thus, in order to avoid the uncertainty over which method would be applied, counsel for settling defendants may further condition the effectiveness of their settlement agreements on several points. One condition may be the court's approval of a specific judgment reduction method that is actually designated in the settlement agreement itself. See, e.g., Eichenholtz, 52 F.3d at 481-82 (proportionate fault method designated in settlement agreement); In re Consolidated Pinnacle West Sec. Litig., 51 F.3d at 196 (proportionate fault method designated in the settlement agreement); TBG, Inc., 36 F.3d at 923 (pro tanto method designated in the settlement agreement); FDIC v. Geldermann, 975 F.2d 695, 699 (10th Cir. 1992) (FDIC director and officer litigation case; pro tanto method in settlement agreement); In re Masters Mates, 957 F.2d at 1025 (contractual provisions in settlement agreement whereby plaintiffs agreed to reduce the judgment obtained against non-settling defendants by the lesser amount under either the proportionate fault method or the pro tanto method); In re Wilshire Sec. Litig., 887 F. Supp. at 237-38 (proportionate fault method designated in the settlement agreement); Alvarado Partners, L.P., 723 F. Supp. at 542-45 (pro tanto method designated in settlement agreement).

Another condition may be the deferment of the selection of the specific judgment reduction method by the court until judgment is rendered. See, e.g., In re Jiffy Lube Sec. Litig., 927 F.2d at 161 (court denied enforceability of such a deferral provision, and vacated the district court's order approving the settlement agreement with this provision); South Carolina Nat'l Bank (Stone I), 749 F. Supp. at 1423 (settlement agreement conditioned on settlement bar order providing that if future judgment is entered against non-settling defendants, then non-settling defendants would be entitled to have the method determined at the time of trial or judgment based upon the controlling legal principles in effect at that time); see also id. at $1432 \mathrm{nn} .8-9$ (court approved this provision on the basis that it accounted for the possibility that the non-settling defendants could still enter into a settlement with plaintiffs). Cf. In re Boesky Sec. Litig., 948 F.2d at 1362-63 (the settlement agreements did not determine the precise method by which the non-settling defendants' judgments would be reduced; the court asserted that deferring this issue would avoid the enormous complexities involved in "hypothesizing findings of fact and law regarding future litigation against non-settling defendants"); see also id. at 1369 (upholding district court determination that resolution of the judgment reduction issues could reasonably be deferred).

Finally, counsel may condition the agreement on court approval of indemnification provisions within the settlement agreement whereby the settling defendants would contract with the plaintiffs for indemnification of certain litigation expenses and any judgments obtained against them by the non-settling defendants in subsequent cross-claims or litigation. Indemnification provisions may be used as an alternative to settlement bar orders where courts in specific jurisdictions have either (i) not made a definitive ruling on which judgment reduction method is most appropriate in partial settlement cases, or (ii) adopted a specific judgment reduction method which, based on the posture of the litigation, the plaintiffs and settling defendants believe will be disadvantageous to their interests upon judgment. See, e.g., TBG, Inc., 36 F.3d at 924-25 (suggesting that bar orders are merely convenient alternatives to indemnity provisions in a settlement agreement and stating such indemnity provisions may serve as a possible alternative to the issuance of bar orders and the selection of judgment reduction methods); In re Boesky Sec. Litig., 948 F.2d at 1362, 1368-69 (holding that settlement agreements may contain any provisions for the indemnification of settling defendants by plaintiffs for amounts secured by non-settling defendants in judgments against settling defendants); In re Del-Val Fin. Corp. Sec. Litig., 868 F. Supp. at 559 (holding that settlement agreements may contain any provisions for the indemnification of settling defendants by plaintiffs for amounts secured by non-settling defendants in judgments against settling defendants).

For example, in $T B G, I n c$, the Tenth Circuit majority recognized that bar orders were only a convenient means of effectuating partial settlements. This is because the plaintiff, in 
In particular, the PSLRA provides that any covered person who settles any 1934 Act private action at any time before final verdict or judgment shall be discharged from all claims for contribution brought by other persons. ${ }^{102}$ The PSLRA directs courts, upon the entry of settlements, to enter bar orders constituting the final discharge of all obligations the settling covered person has to the plaintiff arising out of the action. Further, the PSLRA provides that such orders shall bar all future claims for contribution arising out of the action both by any person against the settling covered person, and by the settling covered person against any person, other than a person whose liability has been eliminated by the settlement of the settling covered person. ${ }^{103}$ The bar order provisions of the PSLRA thus extinguish contribution actions by non-settling defendants against settling defendants, and by settling defendants against non-settling defendants and other persons, except against those who have unequivocally and unfairly benefitted from the settlement. ${ }^{104}$

\section{Partial Settlements and Judgment Reduction}

The PSLRA resolves one of the more complex debates in federal securities litigation by providing for a statutory judgment reduction method. Although the initial securities reform bills incorporated the pro rata, pro tanto, and/or the proportionate fault judgment reduction methods in their provisions, ${ }^{105}$ the 1995 legislation chose not to adopt any of these methods directly. Instead, Congress opted to embrace a version of the capped proportionate fault judgment reduction method derived from the federal district court's decision in In re Del-Val Financial Corp. Securities Litigation. ${ }^{106}$ In order to comprehend the magnitude of the new

lieu of a pro tanto judgment reduction without a bar order, could protect the settling defendants through indemnification agreements against claims by the non-settling defendants, or agreements to defend the settling defendants and pay for their litigation expenses in defending against those claims. See TBG, Inc., 36 F.3d at 924 . Justice White observed in his concurring opinion, however, that the Supreme Court in McDermott frowned upon the indemnification approach, stating that such agreements, while removing the disincentive to settle, added "yet another potential burden on the courts, an indemnity action between the settling defendant and the plaintiff." See id. at 933 (White, J., sitting by designation, concurring in part and concurring in judgment) (quoting McDermott, 511 U.S. at 212). Justice White further recognized that the Supreme Court's reasons for finding a pro tanto credit without a bar order, but coupled with indemnity agreements, unattractive, "are obviously in no way dependent upon the fact that $M c$ Dermott arose in admiralty." Id. at 933 n.6.

102. PSLRA, supra note $11, \S 21 \mathrm{D}(\mathrm{g})(7)(\mathrm{A}), 15$ U.S.C. $\$ 78 \mathrm{u}-4(\mathrm{~g})(7)(\mathrm{A})$.

103. Id. $\S 21 \mathrm{D}(\mathrm{g})(7)(\mathrm{A})(\mathrm{i})-(\mathrm{ii}), 15$ U.S.C. $\$ 78 \mathrm{u}-4(\mathrm{~g})(7)(\mathrm{A})(\mathrm{i})$-(ii).

104. Note that by its express terms, the PSLRA bar provisions prohibit future claims for contribution. Whether such bar orders will be construed to preclude suits based on alleged violations of federal and state law not technically brought as "contribution claims" remains to be seen. See generally Eichenholtz, 52 F.3d at 486 n.14; TBG, Inc., 36 F.3d at 928-29; In re U.S. Oil \& Gas Litig., 967 F.2d at 496 n.5; In re Masters Mates, 957 F.2d at 1032-33; MFS Mun. Income Trust, 751 F. Supp. at 285-86; Steven W. Hansen, Settling Securities Class Actions: Protecting Against Third Party Claims, 28 Rev. Sec. \& Comm. Reg. 1 (1995).

105. See, e.g., Testimony of Arthur Levitt, supra note 90.

106. 868 F. Supp. 547 (S.D.N.Y. 1994). For further discussion, see infra notes 170-82 and accompanying text. 
judgment framework, it is useful to initially review the judgment reduction methods and recent developments in this area. Moreover, prePSLRA case law remains important for actions brought under the 1933 Act, other federal securities statutes, and state law.

\section{Pre-PSLRA Partial Settlements: Judgment Reduction Methods in Multidefendant Securities Actions}

If a court issues a settlement bar order in a given multidefendant securities action, notwithstanding the complications presented by the settlement agreements and posture of the non-settling defendants, the court would be expected to compensate the non-settling defendants for the loss of their statutory or federal common law rights to contribution under the securities laws. Thus, courts have generally attempted to select a judgment reduction method that serves to reduce the judgments obtained by plaintiffs against non-settling defendants by a certain amount in order to reflect the non-settling defendants' loss of those rights. Prior to enactment of the 1995 legislation, courts adopted specific judgment reduction methods in various multidefendant securities actions, but the views of such courts lacked unanimity. ${ }^{107}$ Three distinguishable judgment reduction methods were formulated, and one alternative method was embraced by courts within the Second Circuit. These methods are (1) the pro rata method, (2) the pro tanto method, (3) the proportionate fault method, and alternatively, (4) the so-called capped proportionate fault judgment reduction method incorporating the "one satisfaction" rule.

\section{a. The Pro Rata Method}

The pro rata method is relatively simple in application. Under this method, courts allocate an equal share of liability from the total judgment to both settling defendants and non-settling defendants. ${ }^{108}$ Hence, if the plaintiffs settled with one of five defendants and the other four were found to be liable to the class, the four non-settling defendants would receive a twenty percent reduction in the total judgment rendered against them. The non-settling defendants would then be jointly and severally liable for the remaining eighty percent of the judgment. ${ }^{109}$ Although the pro rata method was applied in several earlier cases ${ }^{110}$ and has some statutory support for its application in Section 11 of the 1933 Act and Sec-

107. See, e.g., In re VMS Ltd. Partnership Sec. Litig., 803 F. Supp. 179, 182 n.1 (N.D. Ill. 1992); USF\&G Co. v. Patriot's Point Dev. Auth., 772 F. Supp. 1565, 1570 (D.S.C. 1991).

108. See, e.g., In re Masters Mates \& Pilot Pension Plan, 957 F.2d 1020, 1028 (2d Cir. 1992); In re Jiffy Lube Sec. Litig., 927 F.2d 155, 161 n.3 (4th Cir. 1991); South Carolina Nat'l Bank v. Stone (Stone II), 139 F.R.D. 335, 342 (D.S.C. 1991).

109. See Hagan \& McLaughlin, supra note 79, at 35 (citing In re Masters Mates, 957 F.2d at 1028).

110. See, e.g., Wassel v. Eglowsky, 399 F. Supp. 1330, 1370 n.77 (D. Md. 1975), aff'd per curiam, 542 F.2d 1235 (4th Cir. 1976); Herzfeld v. Laventhol, Krekstein, Horwath \& Horwath, 378 F. Supp. 112, 136 (S.D.N.Y. 1974), modified on other grounds, 540 F.2d 27 (2d Cir. 1976). 
tions 9(e) and 18(b) of the 1934 Act, ${ }^{111}$ most courts criticized this method as being rigid and inequitable, and accordingly rejected its application. ${ }^{112}$

\section{b. The Pro Tanto Method}

The pro tanto method mandates that plaintiffs receive the full amount of damages awarded and that the non-settling defendants receive a judgment reduction in the amount paid to the plaintiffs in settlement. ${ }^{113}$ Under this method, courts recognize that non-settling defendants tend to bear the risk of an inadequate settlement by the plaintiffs. ${ }^{114}$ For example, suppose that a plaintiff-class sued five defendants and that prior to trial the class settled with one defendant for $\$ 5$ million, and thereafter a settlement bar order was entered precluding contribution against the settling defendant. The jury, thereafter, renders a verdict finding that the

111. Section 11(f) of the 1933 Act and $\S \S 9(\mathrm{e})$ and $18(\mathrm{~b})$ of the 1934 Act all state in part that "every person who becomes liable to make any payment under this section may recover contribution as in cases of contract from any person who ... would have been liable to make the same payment." 15 U.S.C. $\$ 77 \mathrm{k}(\mathrm{f})$ (emphasis added); see id. $\S 78 \mathrm{i}(\mathrm{e})$; id. $\S 78 \mathrm{r}(\mathrm{b})$. As common law contract cases use the pro rata method, the language of these sections may indicate that this method would be an appropriate method under the 1933 and 1934 Acts. See Hagan \& McLaughlin, supra note 79, at 36. Cf. Smith v. Mulvaney, 827 F.2d 558, 561 (9th Cir. 1987) (observing that although the legislative history of $\S 11$ (f) is quite sparse, the language therein purporting to allocate contribution liability "as in cases of contract" seems to imply a pro rata allocation; but holding that contribution, as specified by $\S 11(f)$ is not pro rata, but is based instead on the actual relative culpabilities of the tortfeasors).

112. See, e.g., Franklin v. Kaypro Corp., 884 F.2d 1222, 1227-28 (9th Cir. 1989) (expressly rejecting the pro rata method application under $\$ 11(\mathrm{f})$ ), cert. denied sub nom. Franklin v. Peat Marwick Main \& Co., 498 U.S. 890 (1990); Mulvaney, 827 F.2d at 561 (expressly rejecting the pro rata method application under $\$ 11$ (f)); Morin v. Trupin, No. 88 Civ. 5743, 1993 U.S. Dist. LEXIS 8882, at *10 (S.D.N.Y. June 27, 1993) (rejecting application of pro rata method in Rule 10b-5 litigation); South Carolina Nat'l Bank (Stone II), 139 F.R.D. at 342-43 (expressly rejecting the pro rata method application under $\$ 11(\mathrm{f})$ ); $U S F \& G$ Co., 772 F. Supp. at 1570 (expressly rejecting the pro rata method application under $\S 11(f)$ ). In addition to rejecting the statutory support argument, supra note 111 and accompanying text, these cases in particular have (i) criticized the arbitrariness of the method; (ii) observed that it does not take various levels of culpability into account when allocating liability; and (iii) asserted that it would deter settlement because at the time of settlement the plaintiff may not be able to predict with certainty how many defendants would in fact be found liable.

113. See, e.g., TBG, Inc., 36 F.3d at 923; In re Masters Mates, 957 F.2d at 1029; In re Jiffy Lube Sec. Litig., 927 F.2d at 160 n.3; Federal Sav. \& Loan Ins. Corp. v. McGinnis, Juban, Bevan, Mullins \& Patterson, P.C., 808 F. Supp. 1263, $1275-76$ (E.D. La. 1992); Biben v. Card, No. 84-0844-CV-W-6, 1991 U.S. Dist. LEXIS 18448, at *10-12 (W.D. Mo. Dec. 10, 1991); South Carolina Nat'l Bank (Stone II), 139 F.R.D. at 342; Vigil v. Finesod, 779 F. Supp. 522, 524 (D.N.M. 1990); MFS Mun. Income Trust v. American Medical Int'l, Inc., 751 F. Supp. 279, 282 (D. Mass. 1990); Dalton v. Alston \& Bird, 741 F. Supp. 157, 159 (S.D. Ill. 1991); In $r e$ Terra-Drill Partnerships Sec. Litig., 726 F. Supp. 655, 656 (S.D. Tex. 1989).

114. See, e.g., TBG, Inc., 36 F.3d at 925 (asserting that the pro tanto method unfairly shifts the risk of low settlements from the plaintiff to the non-settling defendants); In re Jiffy Lube Sec. Litig., 927 F.2d at 161; Kaypro Corp., 884 F.2d at 1230; FDIC v. Deloitte \& Touche, 834 F. Supp. 1155, 1160 (E.D. Ark. 1993); Harris v. Agrivest Ltd. Partnership II, 818 F. Supp. 1042, 1044-45 (E.D. Mich. 1993); USF\&G Co., 772 F. Supp. at 1576; United States v. Western Processing Co., 756 F. Supp. 1424, 1430 (W.D. Wash. 1990); Alvarado Partners, L.P. v. Mehta, 723 F. Supp. 540, 553 (D. Colo. 1989), appeal dism'd as moot, 936 F.2d 582 (10th Cir. 1991); In re Sunrise Sec. Litig., 698 F. Supp. 1256, 1258-61 (E.D. Pa. 1988). 
settling defendant was eighty percent at fault and awards $\$ 40$ million in damages. The other four non-settling defendants would then be jointly and severally liable for $\$ 35$ million even though the jury found them collectively to be only twenty percent at fault. ${ }^{115}$ Thus, because the application of the pro tanto method may result in disproportionate non-settling defendant liability due to inadequate settlements, many courts recognized the need to conduct fairness hearings prior to approval of the settlement in an attempt to ensure that the settlement was fair and equitable to nonsettling defendants. ${ }^{116}$

These fairness hearings are intended to be separate and distinct from the examination of whether a settlement is fair and equitable to a respective plaintiff-class under Rule 23(e) of the Federal Rules of Civil Procedure. Many of the factors used in either instance, however, tend to overlap to some extent. The factors used in non-settling defendant fairness hearings tend to focus on (1) the presence of collusion between the plaintiffs and settling defendants; (2) estimates of the settling defendants' culpability relative to the other non-settling defendants; (3) whether a larger judgment against the settling defendants may be collectible; and (4) the participation of a judge or magistrate in the settlement negotiations. ${ }^{117}$ Nonetheless, perceptions remain that good faith hearings are ineffective to prevent the shifting of inadequate settlement risk to the nonsettling defendants. ${ }^{118}$

Prior to 1994, the Second Circuit was considered one of the leading jurisdictions applying the pro tanto method in multidefendant securities actions. ${ }^{119}$ This perception was largely drawn from the Second Circuit's decision in Singer v. Olympia Brewing Co. ${ }^{120}$ In Singer, the plaintiff sued

115. See also the example provided by the Supreme Court in McDermott, 511 U.S. at 212 n.14.

116. See, e.g., TBG, Inc., $36 \mathrm{~F} .3 \mathrm{~d}$ at 926 (if the pro tanto method is considered, a fairness hearing is required before the court authorizes it); In re Masters Mates, 957 F.2d at 1029 (if the pro tanto method is considered, a fairness hearing is required before the court authorizes it); In re Jiffy Lube Sec. Litig., 927 F.2d at $161 \mathrm{n.3}$ (if the pro tanto method is considered, a fairness hearing is required before the court authorizes it). In addition, the state of California specifically requires fairness hearings prior to approving settlements in cases wherein bar orders or similar covenants not to sue are used. See Kaypro Corp., 884 F.2d at 1224-25 n.1; Miller v. Christopher, 887 F.2d 902, 906-07 (9th Cir. 1989); Tech-Bilt, Inc. v. Woodward-Clyde \& Assoc., 698 P.2d 159 (1985).

117. See, e.g., In re Masters Mates, 957 F.2d at 1031-32; In re Meldrige, Inc. Sec. Litig., 837 F. Supp. 1076, 1080-81 (D. Ore. 1993); In re Drexel Burnham Lambert Group, Inc., 146 B.R. 98, 104 (S.D.N.Y. 1992); TBG, Inc. v. Bendis, 811 F. Supp. 596, 600, 605-07 (D. Kan. 1992), rev'd and remanded on other grounds, 36 F.3d 916 (10th Cir. 1994); In re NBW Commercial Paper Litig., 807 F. Supp. at 807; Biben, 1991 U.S. Dist. LEXIS 18448, at *1117; USF\& G Co., 772 F. Supp. at 1573; South Carolina Nat'l Bank (Stone II), 139 F.R.D. at 344; MFS Mun. Income Trust, 751 F. Supp. at 282-85; In re NuCorp Energy Sec. Litig., 661 F. Supp. at 1408; see also Hagan \& McLaughlin, supra note 79, at 38.

118. See, e.g., TBG, Inc., 36 F.3d at 932 (White, J. sitting by designation, concurring) (stating that the pro tanto method, even if tamed with a good faith hearing, is "manifestly inadequate"); Kaypro Corp., 884 F.2d at 1230 (stating that the pro tanto method, even if tamed with a good faith hearing, is inadequate); $U S F \& G$ Co., $772 \mathrm{~F}$. Supp. at 1572-74 (stating that the pro tanto method, even if tamed with a good faith hearing, is inadequate).

119. Hagan \& McLaughlin, supra note 79 , at 38 .

120. 878 F.2d 596 (2d Cir. 1989), cert. denied, 493 U.S. 1024 (1990). 
two defendants in separate actions for violations of the securities laws and the Racketeer Influenced and Corrupt Organizations Act ("RICO"). The plaintiff settled with one defendant and won a judgment against the other non-settling defendant. The non-settling defendant's judgment was then reduced by the trial court in the amount of the settling defendant's settlement payment. ${ }^{121}$ The plaintiff argued that this reduction was improper, stressing that the settling defendant in fact settled both securities and RICO claims and that the RICO claim could have resulted in treble damages. Hence, the plaintiff argued that the settlement payment should be deducted not from the amount to be recovered under the judgment against the non-settling defendant, but rather from the highest amount of "provable damages" that could have been recovered against the settling defendant. ${ }^{122}$ Not surprisingly, the Second Circuit in Singer rejected this argument, reasoning that the settlement amount was to be deducted from "the claim or judgment in the litigated case," and not by some speculative amount that the plaintiff had sought. ${ }^{123}$

A key aspect of the decision was that the plaintiff had not claimed to have suffered more than one injury even though the settling defendant and non-settling defendant had separately violated the securities laws. ${ }^{124}$ The Second Circuit upheld the district court's judgment reduction and adopted the "one satisfaction" rule, which provides that when a plaintiff receives a settlement from one settling defendant, the non-settling defendant is entitled to a judgment reduction equal to the settlement amount for any judgment the plaintiff obtained against the non-settling defendant as long as both the settlement and judgment represented common damages. ${ }^{125}$ Thus, the Singer case made two main points: first, that judgment reduction in accordance with the one satisfaction rule is based on the judgment in the litigated case; and second, that where both a settlement and judgment compensated a plaintiff for the same injury, the non-settling defendant is entitled to a judgment reduction in the amount of the prior settlement paid by the settling defendant(s). ${ }^{126}$

Following the Singer decision, courts in other jurisdictions adopted the pro tanto method and incorporated the Singer analysis into their rulings. ${ }^{127}$ Several other courts observed, however, that no settlement bar order was entered in Singer and therefore the case did not address whether the non-settling defendant(s) could sue the settling defendant(s) for contribution in excess of the judgment reduction. ${ }^{128}$ Subsequently, in

121. Id. at $597-98$.

122. Id. at 600 .

123. Id. at 601 .

124. Id. at $600-01$.

125. Id. at 600 .

126. See In re Masters Mates, 957 F.2d at 1030 (citing Singer, 878 F.2d at 600-01).

127. See, e.g., FDIC v. Mmahat, 907 F.2d 546, 550 (5th Cir. 1990), cert. denied, 499 U.S. 936 (1991); Dalton, 741 F. Supp. at 159-60; In re Terra-Drill Partnerships Sec. Litig., 726 F. Supp. at 656-57.

128. See, e.g., Kaypro Corp., 884 F.2d at 1230 (observing difficulties presented by the application of Singer when the settlement involves an accompanying bar order); USF\&G 
In re Masters Mates, ${ }^{129}$ an ERISA ${ }^{130}$ case involving a partial settlement and bar order, the Second Circuit held that the settlement agreement and accompanying bar order incorporating a judgment reduction method before it must conform to the one satisfaction rule announced in Singer. ${ }^{131}$ The Second Circuit considered both the proportionate fault method and the pro tanto method. In contrasting the two methods, the Second Circuit found that the proportionate fault method raised several problems, and that the pro tanto method combined with a fairness hearing "is more likely to be consistent with equitable principles suggesting that damages should be apportioned in accordance with fault." 132 As the settlement agreement, the bar order before it, and the district court's fairness hearing did not conform to the one satisfaction rule and impermissibly eliminated state law claims that were unrelated to the ERISA claims, the Second Circuit invalidated the bar order without adopting a specific judgment reduction method. ${ }^{133}$ After Masters Mates, the federal district courts of the Second Circuit remained divided as to which judgment reduction method should be adopted in multidefendant securities actions. ${ }^{134}$

\section{c. The Proportionate Fault Method}

The proportionate fault method generally prescribes that the judgments against non-settling defendants will be reduced according to a determination of the percentage of fault attributable to settling defendants and other third parties, either through judicial or jury findings. ${ }^{135}$ Prior

Co., 772 F. Supp. at 1571 ("No bar order was discussed in Singer, and the decision did not address the policy question of what credit method would be required to compensate the non-settling defendant for the barring of his equitable right to contribution"). Moreover, in In re Masters Mates, 957 F.2d at 1030, the Second Circuit additionally recognized this point. Id. ("Conspicuous by its absence is what Singer did not say. It did not address whether Olympia could sue Loeb Rhoades for contribution in excess of the judgment reduction."). See also id. at 1031 (observing that in In re Boesky Sec. Litig., 948 F.2d 1362 (2d Cir. 1991), the court did not adopt a method of judgment reduction but recognized that settlement bar orders were often desirable because they facilitated settlement).

129. In re Masters Mates \& Pilots Pension Plan, 957 F.2d 1020 (2d Cir. 1992).

130. See Employee Retirement Income Security Act of 1974, 29 U.S.C. $\$ \$ 1001-1461$ (1990).

131. In re Masters Mates, $957 \mathrm{~F} .2 \mathrm{~d}$ at 1031.

132. Id. at 1029. Cf. Donovan v. Robbins, 752 F.2d 1170, 1180-81 (7th Cir. 1985) (ERISA case adopting proportionate fault method).

133. 957 F.2d at 1032 .

134. See, e.g., Cortec Indus. v. Sum Holding, L.P., 839 F. Supp. 1021, 1026-27 (S.D.N.Y. 1993) (adopting pro tanto method); Morin v. Trupin, No. 88 Civ. 5743, 1993 U.S. Dist. LEXIS 8882, at *15-17 (S.D.N.Y. June 27, 1993) (adopting proportionate fault method); Bragger v. Trinity Capital Enter. Corp., No. 92 Civ. 2124, 1993 U.S. Dist. LEXIS 10087, at *3-9 (S.D.N.Y. July 22, 1993) (adopting pro tanto method under the In re Masters Mates opinion, but recognizing that the proportionate fault method was the better method to adopt), vacated as moot, 30 F.3d 14 (2d Cir. 1994).

135. See, e.g., Kaypro Corp., 884 F.2d at 1231 (adopting the proportionate fault rule in $\$ 10$ (b) class action litigation); Mulvaney, 827 F.2d at 560-61 (adopting the proportionate fault method in $\$ 10$ (b) litigation); In re VMS Lid. Partnership Sec. Litig., 803 F. Supp. at $182 \mathrm{n} .1$ (explaining its rationale for adopting the proportionate fault method in unpublished opinion previously cited therein). 
to 1994, many federal courts outside of the Second Circuit adopted the proportionate fault method for purposes of partial settlements in multidefendant securities actions. ${ }^{136}$

Perhaps the leading decision adopting the proportionate fault method in this context was Franklin v. Kaypro Corp., ${ }^{137}$ a class-action securities fraud action in connection with an initial public offering wherein the facts alleged potentially gave rise to cross claims and counterclaims based on contribution or indemnity. ${ }^{138}$ In Kaypro, the Ninth Circuit reaffirmed its holding in a previous case ${ }^{139}$ that contribution in this instance was based not on pro rata principles, but rather on the actual relative culpabilities of the tortfeasors. ${ }^{140}$ The Ninth Circuit examined the merits of the pro tanto method coupled with a good faith hearing and squarely rejected application of this method, primarily on the premise that plaintiffs would be tempted to engage in collusion with settling defendants to fund litigation against the wealthier non-settling defendants. Hence, according to the court, the pro tanto method encourages excessive judgments against non-settling defendants relative to their degree of fault. ${ }^{141}$ The court thereupon adopted the proportionate fault method as consistent with three primary criteria: (1) the statutory goal of punishing each wrongdoer; (2) the equitable goal of limiting liability to relative culpability; and (3) the policy goal of encouraging settlement. ${ }^{142}$

\section{i. McDermott, Inc. v. AmClyde: The U.S. Supreme Court Adopts the Proportionate Fault Method in Admiralty Law}

Prior to the Supreme Court's decision in McDermott, Inc. v. AmClyde, ${ }^{143}$ there appeared to be broad support in favor of adopting either the pro tanto or the proportionate fault judgment reduction method. ${ }^{144}$

136. See, e.g., cases cited supra note 135 .

137. 884 F.2d 1222 (9th Cir. 1989), cert. denied sub nom. Franklin v. Peat Marwick Main \& Co., 498 U.S. 890 (1990).

138. Id. at $1222-25$. The settlement agreement at issue was expressly conditioned upon the issuance of a bar order precluding the non-settling defendants from seeking contribution against the settling defendants. The non-settling defendants argued that this bar order impermissibly infringed on their rights to full contribution from the settling defendants. Id. at 1225 .

139. See Smith v. Mulvaney, 827 F.2d 558, 561 (9th Cir. 1987).

140. Kaypro Corp., 884 F.2d at 1226.

141. Id. at 1230-31. In addressing the merits of the pro tanto method, the Ninth Circuit initially observed that the strongest argument in favor of its adoption was that it would not violate the one satisfaction rule delineated in Singer. Id. at 1230. See also US Indus., Inc. v. Touche Ross \& Co., 854 F.2d 1223, 1236 (10th Cir. 1988) ("It is a fundamental legal principle that an injured party is ordinarily entitled to only one satisfaction for each injury."). The court opined that the advantages related to this rule, however, were "illusory" and specifically found that (i) the one satisfaction rule arguably did not apply to the facts before it; and (ii) it was not entirely clear that the rule applied in partial settlements at all, as it was based in common law, and contribution was a statutorily vested right. Kaypro Corp., 884 F.2d at $1231-32$.

142. See 884 F.2d at 1231

143. 511 U.S. 202 (1994).

144. See M. Patricia Adamski, Contribution and Settlement In Multiparty Actions Under Rule 10b-5, 66 IowA L. REV. 533 (1981); Lewis A. Kornhauser \& Richard L. Revesz, Settle- 
In McDermott, the Court set forth its rationale favoring the proportionate fault method in a case governed by admiralty law. The Supreme Court held that in the multidefendant partial settlement context, non-settling defendant liability to the plaintiff in question must be reduced according to the proportionate fault of the settling defendants, as determined by the factfinder. In adopting the proportionate fault method, the Court held that the settling defendants could not be liable for contribution to the non-settling defendants "because the non-settling defendants pay no more than their share of the judgment."145 In considering the various judgment reduction methods, the Court found that three factors comprised the paramount selection criteria: (1) consistency with the equitable apportionment of fault approach in admiralty law precedent; ${ }^{146}(2)$ promotion of settlement; ${ }^{147}$ and (3) judicial economy. ${ }^{148}$ In its opinion, the Supreme Court essentially compared and contrasted two judgment reduction methods: the proportionate fault method and the pro tanto approach without the recognition of a right to contribution against set-

ments Under Joint and Several Liability, 68 N.Y.U. L. Rev. 427 (1993); Vincent P. Liberti, Joint and Several Liability Under Rule 10b-5: The Apportionment of Liability For Contribution Claims Involving Non-Settling Defendants, 7 DEPAul Bus. L.J. 45 (1994); Philip M. Nichols, Symmetry and Consistency and the Plaintiff's Risk: Partial Settlement and the Right of Contribution In Federal Securities Actions, 19 DEL. J. CoRP. L. 1 (1994); Jonathan M. Silver, Contribution Under the Securities Acts: The Pro Rata Method Revisited, 1992/1993 Ann. Surv. Am. L. 273 (1994); Ronald A. Dabrowski, Note, Proportionate Liability In $10 b-5$ Reckless Fraud Cases, 44 DukE L.J. 571 (1994); Paul Holewinski, Note, Defining "Fair Share" In Defendants' 10b-5 Actions For Contribution From Joint Tortfeasors In the Wake of Musick, Peeler \& Garrett v. Employers Insurance of Wausau, 38 ST. LoUis U. L.J. 797 (1994).

145. 511 U.S. at 209. But for the PSLRA, the choice of a "best" judgment reduction method in reality could be a fact dependent inquiry, largely based on (i) the nature of the settling defendants' and non-settling defendants' conduct in question, (ii) the timing and motivations of the particular settlement, (iii) the extent to which discovery is completed, and (iv) overall aspects of fairness to the settling defendant(s), the non-settling defendant(s) and the plaintiff(s) or plaintiff-class. Application of this ad hoc approach arguably would wreak havoc in complex multidefendant partial settlement securities actions.

146. Id. at 211. The Supreme Court generally has permitted admiralty defendants to pursue contribution actions against one another. See, e.g., Cooper Stevedoring Co. v. Fritz Kopke, Inc., 417 U.S. 106 (1973). In United States v. Reliable Transfer Co., 421 U.S. 397, 410-11 (1975), the Supreme Court replaced the divided damages rule, which required an equal division of property damages whatever the relative degree of fault may have been, with a rule requiring that damages be assessed on the basis of proportionate fault when such an allocation can reasonably be made. Although the divided damages rule avoided the difficulty of determining comparative degrees of negligence, the Court concluded that it was "unnecessarily crude and inequitable" and that "[p]otential problems of proof in some cases hardly require adherence to an archaic and unfair rule in all cases." Id. at 407 . Thus, since the Reliable Transfer decision, liability in admiralty actions has ordinarily been assigned to each responsible party according to relative fault; consequently, contribution in admiralty is calculated according to relative fault principles and, thus, a defendant forced (by operation of joint and several liability) to pay the plaintiff more than its equitable share of a damage award is allowed to seek monies from any defendant who has underpaid its equitable share. See TBG, Inc., 36 F.3d at 931 (White, J., sitting by designation, concurring in part and concurring in the judgment) (citing Leger v. Drilling Well Control, Inc., 592 F.2d 1246 (Sth Cir. 1979)).

147. 511 U.S. at 211.

148. Id. 
tling defendants. ${ }^{149}$ Thus, although the precise circumstances before the Court did not involve settlement agreements or settlement bar orders, the pro tanto alternative considered by the Court was the practical equivalent to the pro tanto method with an accompanying settlement bar order. ${ }^{150}$

In considering the promotion of settlements, the Supreme Court observed that the effect of the two methods was ambiguous, and that either method may be preferable given different sets of facts. Accordingly, the Court concluded its analysis in this regard by stating that "[r]ecognition of the reality that a host of practical considerations may be more signifcant than stark hypotheticals persuades us that the pro tanto rule has no clear advantage in promoting settlements." 151 In considering judicial economy, the Court found that the effect of either of the two methods was also ambiguous, and opined that "[o]nce the pro tanto rule is coupled with a good faith hearing, ... it is difficult to determine whether the pro tanto or proportionate share approach best promotes judicial economy." 152 Hence, similar to its analysis under the promotion of settlement factor, the Court perceived that the pro tanto rule "has no clear advantage with respect to judicial economy."153

149. Id. at 209-11.

150. See TBG, Inc., 36 F.3d at 931 n.3, 932 n.5 (White, J., sitting by designation, concurring in part and concurring in the judgment).

151. 511 U.S. at 215-16. After considering the effects of strategic behavior, litigation costs, and whether the probabilities of the defendants' being found liable at trial are "independent" or "correlated," the Court notes that "neither rule is consistently better than the other." Id. at 1469 n.24 (quoting Kornhauser \& Revesz, supra note 144, at 492). In addition, in comparing the pro tanto and proportionate fault methods, these commentators generally assume that the pro tanto rule is implemented without good faith hearings. They assert that good faith hearings "mak[e] the pro tanto set-off rule relatively less desirable from the perspective of inducing settlements than the apportioned [i.e. proportionate] share set-off rule." Kornhauser \& Revesz, supra note 144, at 476, quoted in 511 U.S. at 216 n.24.

152. 511 U.S. at 216 . It is worth noting that, in the process of making its point concerning the inadequacy of good-faith hearings, the Court takes issue with the trial court's endorsement of such a hearing in the case at bar. Id. at 213 n.18.

153. Id. at 217. The Court remarked:

Under either approach, the relative fault of the parties will have to be determined. Under the pro tanto approach, the settling defendant's share of responsibility will have to be ascertained at a separate, pretrial hearing. Under the proportionate share approach, the allocation will take place at trial. The pro tanto approach will, therefore, only save judicial time if the good-faith hearing is quicker than the allocation of fault at trial. Given the cursory nature of most good-faith hearings, this may well be true. On the other hand, there is reason to believe that reserving the apportionment of liability may save more time. First, the remaining defendant (or defendants) may settle before trial, thus making any determination of relative culpability unnecessary. In addition, the apportionment of damages required by the proportionate share rule may require little or no additional trial time. The parties will often need to describe the settling defendant's role in order to provide context for the dispute. Furthermore, a defendant will often argue the "empty chair" in the hope of convincing the jury that the settling party was exclusively responsible for the damage.

Id. at 216-17. See also id. at 216 n.24, 217 n.26 (observing that the analysis would become more complicated if the settlement covered more items of damages). Notably, in the process of analyzing which of these methods should be utilized in admiralty cases, the 
The $M c$ Dermott Court thus analyzed the proportionate fault and pro tanto methods in the multidefendant partial settlement context, concluding that, on the whole, the proportionate fault method was a slightly better choice than the pro tanto method in admiralty cases. Although the $M c D e r m o t t$ decision was rendered in the context of federal admiralty law, the decision predictably and immediately influenced partial settlement analysis in multidefendant securities actions. ${ }^{154}$

\section{ii. TBG, Inc. v. Bendis: The Tenth Circuit Majority and Justice White Diverge on McDermott}

The extent to which the McDermott decision would be extended to securities actions (along with several other previously unaddressed partial settlement issues) came into focus with the Tenth Circuit majority's decision in $T B G$, Inc. v. Bendis. ${ }^{155}$ In $T B G$, the Tenth Circuit panel majority squared off against Justice Byron R. White, sitting by designation on the Tenth Circuit panel, with respect to construing post-McDermott partial settlement issues in multidefendant securities litigation. Although the procedural history of the case is somewhat complex, the primary issue before the Tenth Circuit was whether the district court erred by approving a settlement wherein the effectiveness of the settlement agreement was conditioned upon the approval of the requested bar order and implementation of the pro tanto judgment reduction method. ${ }^{156}$

The Tenth Circuit majority in $T B G$ concluded that bar orders are permissible only where a court or jury assesses proportional fault, thereby awarding the equivalent of a contribution claim. As neither the district

Supreme Court acknowledged that as a general proposition the liability of admiralty defendants to plaintiffs is premised upon joint and several liability. Id. at 220 .

154. For example, shortly after the Supreme Court decided McDermott, the Second Circuit considered the appeal in Bragger v. Trinity Capital Enter. Corp., No. 92 Civ. 2124, 1993 U.S. Dist. LEXIS 10087, at *3-9 (S.D.N.Y. July 22, 1993) (adopting the pro tanto method under the In re Masters Mates opinion, but recognizing that the proportionate fault method was the better method to adopt). Although the appeal was dismissed and the judgment below vacated on grounds of mootness, the Second Circuit commented in dicta that:

It would seem unwise in the present instance to leave standing the district court ruling that any judgment against appellant be reduced on a pro tanto basis. We think it imprudent in light of a recent unanimous decision of the Supreme Court holding, after thorough analysis of the pro tanto and proportional judgment reduction methods, that at least in admiralty suits for damages, the proportional reduction approach is best.

Bragger v. Trinity Capital Enters. Corp., 30 F.3d 14, 17 (1994).

In addition, in the Cortec Indus. case, a district court declared a "moratorium on all procedures" with respect to determining the parameters of a pro tanto fairness hearing and ordered briefing on the issue of whether McDermott applied to maritime cases only or to all cases generally. Cortec Indus. v. Sum Holdings, L.P., 858 F. Supp. 34, 35 (S.D.N.Y. 1994). In a subsequent opinion in Cortec Indus., the court wrote that, after briefing the question of whether McDermott applied to the securities law context, the parties therein accepted that proportionate fault was to be the governing method in the case at bar. See Cortec Indus. v. Sum Holdings, L.P., No. 90 Civ. 0165, 1994 U.S. Dist. LEXIS 18640, at *23 (S.D.N.Y. Dec. 29, 1994).

155. 36 F.3d 916 (10th Cir. 1994).

156. Id. at 923. 
court nor the jury had determined the settling defendants' proportional fault, ${ }^{157}$ the district court had no power to bar the non-settling defendants' contribution claims and thus its order had impermissibly infringed on such contribution rights. ${ }^{158}$ Justice White, although concurring that no need existed to direct the entry of a specific judgment reduction method, ${ }^{159}$ disagreed with the majority's analysis and posited that the McDermott decision should be extended to multidefendant securities actions. ${ }^{160}$

The Tenth Circuit majority held that McDermott was inapplicable to the facts and circumstances before it. The majority essentially supported its conclusion by distinguishing McDermott on the grounds that (1) the $M c D e r m o t t$ opinion only required use of the proportionate fault judgment reduction method in admiralty cases, (2) the settlement in McDermott did not mandate the selection of a particular judgment reduction method, and (3) no bar order was at issue in McDermott. ${ }^{161}$ Countering these assertions, Justice White observed that the pro tanto method without the recognition of a right to contribution for the non-settling defendant(s), which represented the "pro tanto" option considered by the Supreme Court in McDermott, was the practical equivalent of a settlement agreement conditioned upon the issuance of a bar order and selection of the pro tanto judgment reduction method. ${ }^{162}$

The Tenth Circuit majority disagreed with Justice White's assertion that the McDermott decision implied that courts could allocate proportionate fault prior to the non-settling defendants' filing of contribution claims against the settling defendants. In its analysis, the court sought to distinguish admiralty law from securities law in the partial settlement con-

157. Id. at 926 .

158. Id. at 923 . Hence, as the settlement agreement was expressly conditioned on the approval of a pro tanto credit with a bar order, and because these conditions could not be provided, the majority found that a partial settlement no longer existed and thus remanded the case without necessarily selecting a particular judgment reduction method. Id.

159. Id. at 933 (White, J., sitting by designation, concurring in part and concurring in the judgment).

160. Id. at 935 .

161. TBG, Inc. v. Bendis, 36 F.3d 916, 923 (10th Cir. 1994).

162. See id. at 930-31 (White, J., sitting by designation, concurring in part and concurring in judgment) (observing that the pro tanto method without recognition of the nonsettling defendants' right to contribution, considered as one judgment reduction option by the Supreme Court in McDermott, "closely mirrors the regime the trial court approved in the $\$ 10$ (b) action now before us: the non-settling defendant is given a pro tanto credit and he is barred from ever seeking further contribution against the settling defendant"); see also id. at $932 \mathrm{n} .5$ (dismissing majority opinion argument that McDermott is distinguishable because the case did not involve a bar order or a settlement agreement conditioned upon the selection of a particular judgment reduction method). Justice White further asserted that $M c D e r m o t t$ "convincingly explains why the pro tanto credit with a bar order infringes upon non-settling defendants' relative fault contribution rights." Id. at 930 (White, J., concurring in part and concurring in the judgment). In short, along the lines of McDermott, Justice White rejected the application of the pro tanto judgment reduction method coupled with a good faith hearing: "The entry of a pro tanto credit with a bar order creates a significant inconsistency with non-settling defendants' relative fault contribution rights under $\$ 10(b)$ just as it does with Reliable Transfer." Id. at 932. 
text. ${ }^{163}$ The majority argued that "admiralty law is comparative, which allows courts to allocate fault among the defendants in deciding the plaintiff's claim, regardless of whether the defendants have filed contribution claims." 164 On the other hand, "[s]ecurities law requires a contribution claim before the court can order the jury to divide damages among the defendants." 165 Hence, the majority concluded:

Although both admiralty law and securities law seek to allocate fault among defendants, they do so in different ways ... A court [in a federal securities law case] cannot assume jurisdiction over a contribution claim that is not before it simply because that claim has the same purpose as a comparative fault or other law that allows the court to allocate fault in the primary claim. ${ }^{166}$

Disagreeing, Justice White pointed out that:

[L]iability in admiralty is fully joint and several, just as it is in tort actions under the Uniform Comparative Fault Act ... and securities actions under $\S 10(\mathrm{~b}) . .$. It is simply that in each regime-admiralty, tort law under the Uniform Comparative Fault Act ... and $\S 10$ (b) - the joint and several liability rule has been tempered with an assurance ... that fault will be distributed according to relative fault when possible. ${ }^{167}$

Justice White acknowledged that if a non-settling defendant's relative share of the judgment was uncollectible, the joint and several liability rule "might well operate to require a reallocation of fault."168 As will be discussed later, Congress incorporated such a reallocation provision in part into Title II of the Litigation Reform Act. ${ }^{169}$

\section{iii. In re Del-Val Financial Corp.: Extending McDermott to Securities Actions for Non-Settling Defendant Partial Settlement Claims}

Irrespective of $T B G$, the proportionate fault method in the post- $M c$ Dermott era generally prevailed as the dominant judgment reduction method of choice in multidefendant securities actions. ${ }^{170}$ A decision that

163. Id. at $927-28$.

164. Id. at 927 (citations omitted).

165. Id. at 928 .

166. $I d$.

167. See TBG, Inc. v. Bendis, 36 F.3d 916, 935 (10th Cir. 1994) (White, J., sitting by designation, concurring in part and concurring in the judgment) (citations omitted).

168. Id. at $935 \mathrm{n} .12$ (citation omitted).

169. See infra notes $183-96$ and accompanying text.

170. For example, one federal district court considered a motion for a bar order by settling defendants in relation to claims alleged by a plaintiff-class that had been certified solely for purposes of settlement. See In re Kendall Square Research Corp. Sec. Litig., 869 F. Supp. 53 (D. Mass. 1994). The court, noting that in federal securities fraud cases "courts routinely enter bar orders against contribution and indemnification in order to facilitate partial settlements," reversed its position from a prior judgment in a similar case and held that the Supreme Court's reasoning in McDermott was "equally applicable" to securities actions. Id. at 54-55 (citations omitted). In considering the $T B G$, Inc. opinion, the district court limited its focus to the majority's observation that "McDermott explains why courts should choose a proportional fault credit when they are free to do so."' Id. at 55-56 (quot- 
received significant attention was In re Del-Val Financial Corp. Securities Litigation. ${ }^{171}$ There, the federal district court considered cross-motions for summary judgment by both non-settling defendants and settling defendants on their cross claims for contribution and indemnification. ${ }^{172}$ While this litigation was pending, the Supreme Court issued its opinion in $M c D e r m o t t$. Thereupon, the settling defendants filed a motion for sum-

ing $T B G$, Inc., 36 F.3d at 922-23). The district court further quoted Justice White's concurring opinion approvingly in dismissing the pro tanto method from consideration. Id. at 55 n.4, 56. Hence, the court in Kendall Square, not constrained by a conditional settlement agreement, could freely apply $M c D e r m o t t$ to invoke the proportionate fault judgment reduction method for purposes of the non-settling defendants' contribution claims. Id. at 56 .

In another case, the district court in $T B G$, Inc., on remand from the Tenth Circuit, agreed with Justice White's concurring opinion in most respects and held that the proportionate fault judgment reduction method was the appropriate method to adopt in this case. See TBG, Inc. v. Bendis, 160 F.R.D. 621, 624 (D. Kan. 1995). The district court, however, took care to expressly "decline to adopt the capped proportionate method used by the court in Del-Val, 868 F. Supp. 547, as urged by [Bendis]." Id. at $624 \mathrm{n} .2$. The district court also stated that based on the language in the Tenth Circuit majority opinion, it would require the actual filing of contribution claims as a jurisdictional prerequisite to the implementation of a judgment reduction method. Id. at 624.

In a third case, Eichenholtz v. Brennan, 52 F.3d 478 (3d Cir. 1995), the Third Circuit considered non-settling defendant objections to a proposed class-action settlement agreement that incorporated a far-reaching bar order and proportionate fault judgment reduction method. Id. at $481-83 \&$ n.8. After holding that the non-settling defendants had standing to contest the class-action settlement, the Third Circuit expressly agreed with federal courts that "have imposed the bar as a matter of federal common law, finding that a fair and equitable settlement bars implied rights of contribution for federal securities claims." See id. at 486 (quoting In re Jiffy Lube Sec. Litig., 927 F.2d at $160 \mathrm{n} .2$ and thus declining to focus on the jurisdictional arguments raised by the Tenth Circuit majority in $T B G$, Inc.). The Eichenholtz court proceeded to adopt the proportionate fault method, emphasizing that the relative culpabilities of both the non-settling defendants and the settling defendants would be determined in the same trial and that the plaintiff-class bore the risk of inadequate settlement. See 52 F.3d at 487 . The Third Circuit likewise cited both the $M c D e r m o t t$ and $T B G$, Inc. opinions approvingly as general support for its conclusion to adopt the proportionate fault method, without elaborating on the specific merits of either decision. See id. at 487 nn.16, 17.

171. 868 F. Supp. 547 (S.D.N.Y. 1994), application for interlocutory appeal denied, 874 F. Supp. 81 (S.D.N.Y. 1995).

172. In a pre-trial conference, the district court had indicated that it would enter a bar order with a judgment reduction based upon the proportionate fault method. See In re Del-Val Fin. Corp. Sec. Litig., 868 F. Supp. 547, 550, 550 n.6 (S.D.N.Y. 1994). The plaintiffclass, however, strongly objected to the proportionate fault method and negotiated its own contractual indemnification provisions as a supplement to the settlement agreement in order to circumvent the bar order and court-ordered judgment reduction method. Id. at 551. The plaintiff-class and settling defendants agreed that if the plaintiff-class won a judgment against the non-settling defendants and if the non-settling defendants obtained a judgment against the settling defendants in a subsequent contribution action, the plaintiff-class would reduce the amount of its judgment against the non-settling defendants by either the settlement amount or the amount of non-settling defendants' judgment for contribution against the settling defendants, whichever was greater. Id. The negotiated supplement also provided that the settling defendants would be obligated to defend in good faith against any contribution claims brought against them and that the settling defendants would not compromise those claims without the prior approval of the plaintiff-class counsel. Id. Relying on a valuation of the settlement offered by the plaintiff-class's expert witness and a statement of counsel that such valuation would not be contested in any subsequent proceedings, the court ordered that any judgment entered against the non-settling defendants would be reduced by that amount, subject to further reduction if the judgment reduction provision in the settlement agreement became applicable. Id. 
mary judgment seeking dismissal of the non-settling defendants' cross claims against them. The non-settling defendants, however, filed a similar motion to dismiss the settling defendants' cross claims. ${ }^{173}$ The district court examined the merits of extending McDermott to securities actions, holding that the decision should be so extended for purposes of the nonsettling defendants' contribution claims against the settling defendants. ${ }^{174}$ Thus, the court dismissed the non-settling defendants' cross claims. ${ }^{175}$ The court found the Supreme Court's statement in McDermott that the proportionate fault rule was consistent with principles of joint and several liability to be "completely persuasive" in partial settlement securities actions. ${ }^{176}$ Accordingly, the court held that the proportionate fault rule ap-

173. Id. at 551. Interestingly, both the non-settling defendants and settling defendants argued that $M c$ Dermott mandated the application of the proportionate fault method to partial settlements in securities actions. The plaintiff-class, however, opposed both the dismissal of these cross claims and the applicability of McDermott because dismissal of these claims would violate the newly incorporated indemnification provisions to the settlement agreement. The plaintiff-class in effect contended that the partial settlement agreement controlled the manner in which the actions for contribution and indemnification must proceed and that dismissing the settling defendants' and non-settling defendants' cross claims would violate the "express terms and spirit" of the agreement. Id. at 551-52. The court disagreed, finding that (i) the non-settling defendants were not parties to the settlement agreement and therefore could not be bound by its terms; and (ii) the express terms of the settlement agreement did not in and of themselves prevent the settling defendants from moving for and being granted summary judgment in this instance. Id. at 552. The court specifically found that the loosely worded agreement only referred to future contingencies and that the judgment reduction provisions did not come into play until there existed a valid judgment for contribution against the settling defendants. Hence, if the extension of the proportionate fault rule extinguished the non-settling defendants' contribution claims, no judgment could be entered against the settling defendants and the judgment reduction provision would be ineffective. $I d$. As the settlement agreement was completely silent regarding this possibility, the court held that the plaintiff-class could not now attempt to read nonexistent binding terms into the settlement agreement in this regard. Id. at 552 . Thus, the court proceeded to the merits. Id. at 552-53.

174. Id. at 555 .

175. Id. The court emphasized that in the case before it, unlike the TBG, Inc. decision adjudicated in the Tenth Circuit, the settlement agreement did not specify a particular judgment reduction method to be applied and, similar to the situation in McDermott, no bar order had yet been entered. Id. at $556 \mathrm{n} .11$. The court also observed that the Second Circuit's dicta in Bragger, 30 F.3d at 17, discussed supra note 154, invited consideration of the possibility that the proportionate fault rule could be extended to partial settlements of securities actions. See 868 F. Supp. at 556 . Hence, the court did not have the more complex jurisdictional questions in connection with issuing bar orders before it, and had more leeway to recognize the proportionate fault method in lieu of the settlement agreement. In other words, nothing stood between extending $M c$ Dermott to the securities action in this case except for the McDermott factors themselves.

176. See $868 \mathrm{~F}$. Supp. at 558 . The specific phrase quoted from $\mathrm{McDermott}$ was as follows:

Joint and several liability applies when there has been a judgment against multiple defendants. It can result in one defendant's paying more than its apportioned share of liability when the plaintiff's recovery from other defendants is limited by factors beyond the plaintiff's control, such as a defendant's insolvency .... [T] he proportionate share rule ... applies only when there has been a settlement. In such cases, the plaintiff's recovery against the settling defendant has been limited not by outside forces, but by its own agreement to settle.

Id. at 557-58 (quoting McDermott, Inc. v. AmClyde, 511 U.S. 202, 220 (1994)). See TBG, Inc., 36 F.3d at 936 (White, J., sitting by designation, concurring in part and concurring in 
plied to multidefendant securities actions for purposes of the non-settling defendant claims, which were therefore rendered unnecessary. ${ }^{177}$

\section{d. The "Capped" Proportionate Fault Judgment Reduction Method and Examination of Settling Defendants' Right to Contribution}

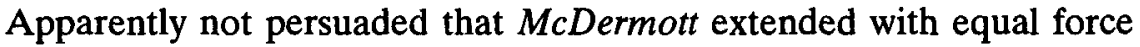
to the settling defendants' contribution action, the district court in In re Del-Val Financial Corp. then proceeded to address the settling defendants' cross claims for contribution against the non-settling defendants and the selection of an appropriate judgment reduction method for these claims. The district court observed that although the Second Circuit had never adopted a particular judgment reduction method, the Second Circuit had nonetheless adopted the one satisfaction rule in securities actions in Singer 178 and reaffirmed its use in partial settlements in In re Masters Mates. ${ }^{179}$ The non-settling defendants argued that the one satisfaction rule could be violated if the settling defendants settled for more than their proportionate share of the judgment and the non-settling defendants were required to pay their proportionate share..$^{180}$

the judgment). In support of its decision, the district court emphasized, among other things, that the Second Circuit had never prescribed a particular judgment reduction method. In re Del-Val Fin. Corp. Sec. Litig., 868 F. Supp. at 559 n.15. Moreover, enhancing equitable apportionment of damages among joint tortfeasors in view of the competing interests of the plaintiff(s), settling defendant(s), and non-settling defendant(s) was of primary importance in securities partial settlements. Id. at 559. In its consideration of interests related to promoting settlement and judicial economy, the district court's analysis largely mirrored that of McDermott, agreeing with the Supreme Court's conclusion that the pro tanto method offered "no clear advantage in promoting settlement" and that neither method possessed any clear advantage in terms of judicial economy. Id. at 560-61 (interests in promoting settlement); id. at 561-62 (judicial economy).

177. See $868 \mathrm{~F}$. Supp. at 562 . The district court's analysis for determining whether $M c$ Dermott extends to federal securities actions removes some of the friction generated by the arguments exchanged between the Tenth Circuit majority and Justice White in TBG, Inc. Of the $\mathrm{McDermott}$ factors considered, the district court only "modified" the first McDermott factor to fit within its analysis, and basically adopted the Supreme Court's approach under the other two factors. This analysis may reflect a feasible accommodation of the Supreme Court's opinion in the multidefendant securities partial settlement context. See id. at 556-59.

178. Id. at 562 (citing 878 F.2d at 599-600). See supra notes 119-134 and accompanying text.

179. 868 F. Supp. at $562 \mathrm{nn} .15,17$ (citing In re Masters Mates, 957 F.2d at 1030-31). The court also noted that its previous order provided that, as required by the one satisfaction rule, any judgment obtained by the plaintiff-class in the trial of the class claims would be reduced by the value of the settling defendant's settlement package as determined by the plaintiff-class expert. Id. at 562 .

180. Id. Although not specifically mentioned in the case, \$28(a) of the 1934 Act may provide the statutory basis against such overcompensation of the plaintiff. See Friedman, supra note 30, at 160 . Section 28 (a) provides in relevant part:

$[\mathrm{N}]$ o person permitted to maintain a suit for damages under the provisions of this chapter shall recover, through satisfaction of judgment in one or more actions, a total amount in excess of its actual damages on account of the act complained of.

15 U.S.C. $\$ 78 b b(a)(1988)$. 
In order to avoid the overcompensation problem and incorporate the one satisfaction rule, the non-settling defendants proposed that the district court reduce any judgment won by the plaintiff-class against the nonsettling defendants by either the settling defendants' proportionate share of the fault or the amount of the settlement, whichever amount was greater. ${ }^{181}$ Upon consideration, the court adhered to the non-settling defendants' approach with one key modification: that the settling defendants could seek contribution from the non-settling defendants for the amount by which the settlement amount exceeded the settling defendants' proportionate share of the judgment in this particular case. ${ }^{182}$ The

181. 868 F. Supp. at 562. This approach was adopted in the PSLRA. See infra notes 183-96 and accompanying text. Cf. FDIC v. Deloitte \& Touche, 834 F. Supp. at 1162, wherein the court addressed the effect of the one satisfaction rule on the proportionate fault judgment reduction method it adopted. The court suggested the same approach suggested by the non-settling defendants in In re Del-Val Fin. Corp. Sec. Litig. as a means of avoiding the one satisfaction rule problem. The court in this particular case, however, was ruling only on a contribution action brought by the non-settling defendants and had no reason to consider the effect of the one satisfaction rule on contribution actions brought by the settling defendant. See In re Del-Val Fin. Corp. Sec. Litig., 868 F. Supp. at 562 n.18. In addition, the In re Del-Val Fin. Corp. Sec. Litig. court observed that adopting the suggested method would have the following immediate consequences:

1. If the settling defendants settled for less than their proportionate share of the fault, the non-settling defendants would pay their proportionate share of the judgment; hence, the settling defendants' contribution action would be unnecessary in this instance. Id. at 563.

2. If, however, the settling defendants settled for more than their proportionate share of the fault, the allocation of payment among settling defendants and non-settling defendants would depend on the permissibility of contribution. If the court precluded the settling defendants from seeking contribution from the non-settling defendants, the settling defendants would pay more than their equitable share of the judgment and would thus suffer the risk of a high settlement. If, however, the court permitted the settling defendants to seek contribution from the non-settling defendants, then each defendant would pay its equitable share of the judgment. Id. at 563 \& n. 19 .

182. See id. at 563 . The reasons set forth by the district court included:

1. The new method ensures compliance with the Supreme Court's focus in McDermott on equitable apportionment of damages among defendants because after resolution of the settling defendants' contribution claims against the non-settling defendants, each defendant would be required to pay its proportionate share of the judgment. Id.

2. The plaintiff-class recovery would remain unaffected by the outcome of the settling defendants' contribution action against the non-settling defendants. Id. at 564 .

3. In accordance with the Supreme Court's allocation of risk in McDermott, the plaintiff-class shouldered the risk of settling for less than the settling defendants' share of the liability whether or not the settling defendants were permitted to bring a contribution action. Id.

4. Although recognition of the settling defendants' contribution rights created the possibility that in some instances there would be a second trial to resolve these claims, interests of judicial economy and promotion of settlement were not enough to deprive the settling defendants of their rights to contribution in this instance. Id.

5. The settling defendants would have a claim for contribution where they settled for more than their equitable share of the damages, which would occur only where the settling defendants overestimated their potential liability to the plaintiffs. Id. (citing McDermott, 511 U.S. at 220 (opining that this event would not occur very often, given the plaintiffs' incentive to settle and to improve its financial posture in litigating against the non-settling defend- 
Second Circuit has not issued an opinion related to this case, so the capped proportionate fault judgment reduction method remains as precedent for settling defendant claims. The influence of this decision is significant because the PSLRA judgment reduction provisions in part incorporate the capped proportionate fault method.

\section{The PSLRA Judgment Reduction Method}

The PSLRA judgment reduction method applies to 1934 Act actions filed after the effective date of the 1995 legislation. ${ }^{183}$ Under the PSLRA, if a covered person enters into a settlement with the plaintiff prior to final verdict or judgment, a bar order is to be entered which discharges the settling covered person's obligations to the plaintiff(s) arising out of the action. Moreover, such bar order precludes claims for contribution by any person against the settling covered person, and by such settling covered person against the non-settling defendants. ${ }^{184}$

If such settlement is entered into by a covered person, the verdict or judgment against the non-settling defendants shall be reduced by the greater of "(i) an amount that corresponds to the percentage of responsibility of that covered person; or (ii) the amount paid to the plaintiff by that covered person."185 A version of this modified judgment reduction

ants)). If the settling defendants' contribution claims against the non-settling defendants were filed prior to the trial of the plaintiff-class claims, however, the claims would be tried together and the jury would reach a verdict without having a second trial, thus eliminating judicial economy concerns. $868 \mathrm{~F}$. Supp. at 564.

6. The court recognized that if the settling defendants were not parties to the action where proportionate fault is determined, the non-settling defendants could "point to the "empty chair" and argue that the settling defendants deserved being allocated the greater share of the fault; and therefore, the plaintiff-class would shoulder the risk that the jury would allocate a lower proportion of fault to the non-settling defendants than the facts warranted. Id. at 565 . The court observed, however, that in the case before it this problem could not occur, as the settling defendants had filed their contribution claims prior to trial and would be required to pursue them before the same jury that would decide the plaintiff-class's claims. Id. Moreover, the court noted that the settling defendants were still contractually obligated under the settlement agreement to assist the plaintiff-class in subsequent litigation. Id. The plaintiff-class objected to the court's implementation of this method because it allegedly negated the carefully negotiated terms of its settlement agreement with the settling defendants. The court, however, similar to its previous analysis of the plaintiff-class settlement agreement arguments in relation to the extension of the McDermott decision to securities actions, noted that the terms of the settlement agreement did not cover this situation. Id. See also supra notes 173-76.

Nonetheless, to diffuse the "empty chair" motive and to avoid inefficiency of judicial resources, it may be appropriate for a court, as a condition to bringing contribution claims, to require parties to file their cross-claims prior to the start of the trial so that all issues of relative fault may be determined by the same jury in the same case.

183. The effective date of PSLRA is December 22, 1995. See supra note 35.

184. PSLRA, supra note $11, \S 21 \mathrm{D}(\mathrm{g})(7)(\mathrm{A}), 15$ U.S.C. $\$ 78 \mathrm{u}-4(\mathrm{~g})(7)(\mathrm{A})$. For discussion of the term "covered" person and the entry of bar orders, see supra notes $26-27,32-43$ and accompanying text.

185. Id. \& $21 \mathrm{D}(\mathrm{g})(7)(\mathrm{B}), 15$ U.S.C. $\S 78 \mathrm{u}-4(\mathrm{~g})(7)(\mathrm{B})$. 
method was advocated in congressional testimony by the SEC as a means of resolving a perceived split among the federal appellate courts, ${ }^{186}$ and further appears to incorporate the "one satisfaction" rule supported by Second Circuit precedent. ${ }^{187}$

Under the PSLRA's approach, the "one satisfaction" rule is enhanced. Plaintiffs cannot recover more than their actual damages. ${ }^{188}$ Indeed, the risk of an inadequate settlement falls on the plaintiffs, resulting in the potential denial of full compensation. For example, assume a verdict of $\$ 10$ million where the covered person settled for $\$ 2$ million but is determined by the factfinder to be sixty percent responsible. In such event, the amount of the verdict would be reduced to $\$ 4$ million, thereby enabling the plaintiffs to recover $\$ 6$ million in total, even though their actual losses are $\$ 10$ million. Moreover, because a bar order is entered precluding claims for contribution, the risk of overpayment in settlement is borne by the settling defendants. On the other hand, parties who litigate rarely will pay more than their percentage of responsibility. ${ }^{189}$ Indeed, depending on the amount of the settlement paid and the culpability of the settling covered persons, parties who litigate may be liable for less than the

186. See Testimony of Arthur Levitt, supra note 90; House Testimony of Arthur Levitt, supra note 44.

187. See supra notes 170-82 and accompanying text. In $M c D e r m o t t$, the Supreme Court considered whether the proportionate fault method violated the one satisfaction rule. There, the Court was urged to apply the one satisfaction rule to reduce a plaintiff's recovery against non-settling defendants in order to ensure that the plaintiff "does not secure more than necessary to compensate him for his loss." 511 U.S. at 218 . The Court decided not to apply the one satisfaction rule in that case, however, and held that even if the court of appeals were correct in finding that the proportionate fault method would overcompensate the plaintiff in that case, it would still not apply the one satisfaction rule because "[t]he law contains no rigid rule against overcompensation." Id. at 219 . The Court further opined that:

It seems probable that in most cases in which there is a partial settlement, the plaintiff is more apt to accept less than the proportionate share that the jury might later assess against the settling defendant, because of the uncertainty of recovery at the time of settlement negotiations and because the nirst settlement normally improves the plaintiff's litigating posture against the nonsettlors. In such cases, the entire burden of applying a proportionate share rule would rest on the plaintiff, and the interest in avoiding overcompensation would be absent.

Id.

188. The PSLRA judgment reduction provisions appear to accommodate $\S 28(\mathrm{a})$ of the 1934 Act. Section 28(a) provides in pertinent part:

[N]o person permitted to maintain a suit for damages of this chapter shall recover, through satisfaction of judgment in one or more actions, a total amount in excess of his actual damages on account of the act complained of.

15 U.S.C. $\$ 78 \mathrm{bb}(\mathrm{a})$. The Supreme Court has held that the correct measure of damages under $\$ 28$ of the 1934 Act is the difference between the fair value of all that the plaintiff received and the fair value of what he would have received had there been no fraudulent conduct. Randall v. Loftsgaarden, 478 U.S. 647, 661-62 (1986) (quoting Affiliated Ute Citizens, 406 U.S. 128, $155(1992)$ ). Hence, $\$ 28$ has had its primary impact in disallowing the recovery of punitive damages under the 1934 Act. See, e.g., Salcer v. Envicon Equities Corp., 744 F.2d 935, 939-40 (2d Cir. 1984).

189. For example, this may occur if certain defendants are insolvent. See PSLRA, supra note $11, \$ 21 \mathrm{D}(\mathrm{g})(4)$; infra notes $197-205$ and accompanying text. 
amount of damages for which they are responsible. ${ }^{190}$ Needless to say, this framework raises legitimate questions relating to investor protection and fairness to all litigants. Consequently, it remains to be seen whether the rationale underlying these provisions of the PSLRA will be applied in cases predating the 1995 legislation or to claims that are outside of its scope (such as actions under the 1933 Act). ${ }^{191}$

Interestingly, the PSLRA's judgment reduction method may deter rather than facilitate settlements. Plaintiffs must exact a settlement corresponding to both the covered settling defendant's percentage of responsibility and damages caused. Potential covered settling defendants, on the contrary, may be impelled to proceed to trial unless they negotiate a clearly beneficial settlement. This strategy appears likely in light of the loss of contribution claims under the PSLRA along with that legislation's provision for proportionate liability for those who act without actual knowledge. ${ }^{192}$

Moreover, the specter of litigating defendants seeking to place culpability upon those who have settled as well as upon those who are not defendants (the "empty chair" scenario) becomes more probable under the PSLRA. ${ }^{193}$ Unlike the rationale seen in such cases as In re Del-Val Financial Corp.,${ }^{194}$ entry of a settlement by a covered person signifies that a bar order shall be issued precluding claims for contribution by or against such covered person. ${ }^{195}$ Hence, settling covered persons under PSLRA have little incentive to combat the "empty chair" scenario, leaving this task solely to the plaintiffs. The end result may be that there will be fewer partial settlements and more cases will proceed to trial against all defendants. ${ }^{196}$

190. See PSLRA, supra note $11, \S 21 \mathrm{D}(\mathrm{g})(7), 15$ U.S.C. $\$ 78 \mathrm{u}-4(\mathrm{~g})(7)$. For example, assume a verdict of $\$ 10$ million where the covered settling person paid $\$ 7$ million and is found $40 \%$ responsible. In such event, the non-settling party's liability would be $\$ 3$ million even though it is $60 \%$ responsible. As noted above, upon entry of settlement, a bar order is entered precluding claims for contribution. Id. See supra notes 183-88 and accompanying text.

191. See cases discussed supra notes 108-82 and accompanying text.

192. See PSLRA, supra note $11, \S 21 \mathrm{D}(\mathrm{g})(2)(\mathrm{B}), 21 \mathrm{D}(\mathrm{g})(7)(\mathrm{A}), 15$ U.S.C. \& 78u$4(\mathrm{~g})(2)(\mathrm{B}), 78 \mathrm{u}-4(\mathrm{~g})(7)(\mathrm{A})$.

193. See supra notes 153,182 . See Pincus, supra note 19 , at 21 (stating that "[t]he jury may assign a share of responsibility to persons not named as defendants in the action").

194. 868 F. Supp. 547 (S.D.N.Y. 1994), discussed supra notes 170-82 and accompanying text.

195. See PSLRA, supra note $11, \S 21 \mathrm{D}(\mathrm{g})(7)(\mathrm{A}), 15$ U.S.C. $\$ 78 \mathrm{u} 4(\mathrm{~g})(7)(\mathrm{A})$.

196. See Avery, supra note 17 , at 365 :

Under the proportionate reduction approach, defendants cannot be saddled with more than their proportionate share of liability simply because the plaintiff settled part of the case too cheaply. As a result, defendants who believe they have meritorious defenses can litigate a case without having to worry that their exposure will be increased due to settlements made by other defendants. The proportionate reduction approach will inevitably result in some cases where defrauded investors are precluded from recovering all of their damages, but that choice would be made by the investors and would be fully within their control.

See also, Rieman et al., supra note 32, at 173 ("Congress's theory, presumably, is that the plaintiff had a choice as to the terms of the settlement, while the nonsettling defendants did 


\section{E. Reallocation of Liability for Uncollectible Shares}

Under the newly adopted proportionate liability framework, Congress intended that a defendant not falling within the joint and several liability regimen (that is, one who acts without actual knowledge) would never be required to pay more than its fair share of the damages in a multidefendant securities action in which all responsible parties are solvent. Dilemmas arise, however, where one or more bankrupt parties is unable to pay their fair share of the damages they have jointly caused. Under the prePSLRA joint and several liability framework, solvent defendants in such cases were required to bear financial responsibility for the liabilities of insolvent co-defendants. ${ }^{197}$ In an unrefined system of proportionate liability, on the other hand, the plaintiffs would absorb entirely the loss of recoverable damages due to such insolvencies. Thus, in this respect, the goal of ensuring that plaintiffs are adequately compensated would be severely undermined. ${ }^{198}$

Fortunately, the PSLRA provides a remedy to these dilemmas by establishing a specific reallocation scheme. Notwithstanding the proportionate liability regimen, the PSLRA provides for the reallocation of liability among covered persons if, upon motion made not later than six months after a final judgment is entered in any private action, the court determines that all or part of the share of the judgment of a covered person is not collectible against that covered person and is also not collectible against a jointly and severally liable covered person. If this is the case, the PSLRA provides that each covered person who is held proportionately responsible under the proportionate liability scheme will be liable for this "uncollectible share" under a specified reallocation formula. ${ }^{199}$ The reallocation formula apparently seeks to ensure that individual plaintiff investors lacking a high net worth are sufficiently com-

not. Beyond that, the authors of the 1995 Act may well have been motivated by their wish to reduce the likelihood, and thus the in terrorem effect, of large damages awards in securities litigation.") (emphasis added).

197. See supra notes $12-13$ and accompanying text.

198. See the following statement by the McDermott Court:

Joint and several liability applies when there has been a judgment against multiple defendants. It can result in one defendant's paying more than its apportioned share of liability when the plaintiff's recovery from other defendants is limited by factors beyond the plaintiff's control, such as a defendant's insolvency. When the limitations on the plaintiff's recovery arise from outside forces, joint and several liability makes the other defendants, rather than an innocent plaintiff, responsible for the shortfall .... [T] he proportionate share rule announced in this opinion applies [only] when there has been a settlement. In such cases, the plaintiff's recovery against the settling defendant has been limited not by outside forces, but by its own agreement to settle. There is no reason to allocate any shortfall to the other defendants, who were not parties to the settlement.

McDermott, 511 U.S. at 220-21 (footnotes omitted) (emphasis added). See also TBG, Inc., $36 \mathrm{~F} .3 \mathrm{~d}$ at $936 \mathrm{n} .16$ (White, J., sitting by designation, concurring in part and concurring in the judgment) (emphasizing this point in McDermott).

199. PSLRA, supra note $11, \S 21 \mathrm{D}(\mathrm{g})(4)(\mathrm{A}), 15$ U.S.C. $\$ 78 \mathrm{u}-4(\mathrm{~g})(4)(\mathrm{A})$. 
pensated and are not saddled with the risk of uncollectibility. ${ }^{200}$

First, the reallocation formula provides that each proportionately liable covered person shall be jointly and severally liable for the uncollectible share if the plaintiff establishes that he or she is an individual whose recoverable damages under the final judgment are equal to more than ten percent of the net worth of such plaintiff and his or her net worth is less than $\$ 200,000 .{ }^{201}$ Second, with respect to any plaintiff not within the foregoing description, the reallocation formula provides that each covered person shall be liable for the uncollectible share in proportion to the percentage of responsibility of that covered person, except that the total liability of a covered person thereunder cannot exceed fifty percent of the proportionate share of that covered person as previously determined under the proportionate liability framework. ${ }^{202}$ In any event, the total payments required pursuant thereto cannot exceed the amount of the uncollectible share. ${ }^{203}$ As with the joint and several and proportionate liability schemes, the PSLRA provides that the procedure for reallocation of uncollectible shares is not to be disclosed to members of the jury.204 Moreover, a covered person against whom the judgment was not collectible is subject to actions for contribution and to any continuing liability to the plaintiff on that judgment. ${ }^{205}$

200. See Pincus, supra note 19 , at 22 .

201. PSLRA, supra note $11, \S 21 \mathrm{D}(\mathrm{g})(4)(\mathrm{A})(\mathrm{i})$-(ii), 15 U.S.C. $\$ 78 \mathrm{u}-4(\mathrm{~g})(4)(\mathrm{A})(\mathrm{i}-\mathrm{ii})$. Presumably, to demonstrate that they are within this category, plaintiffs would file individual "proof of claim" forms. Defendants should be entitled to discovery to test the veracity of these assertions. See Pincus, supra note 19, at 22. For purposes of the reallocation scheme, the term "net worth" is "determined as of the date immediately preceding the date of the purchase or sale (as applicable) by the plaintiff of the security that is the subject of the action, and shall be equal to the fair market value of assets, minus liabilities, including the net value of the investments of the plaintiff in real and personal property (including personal residences)." PSLRA, supra note $11, \S 21 \mathrm{D}(\mathrm{g})(4)(\mathrm{A})(\mathrm{iii})$, 15 U.S.C. \& 78u4(g)(4)(A)(iii).

202. PSLRA, supra note $11, \S 21 \mathrm{D}(\mathrm{g})(4)(\mathrm{A})(\mathrm{ii}), 15$ U.S.C. $\S 78 \mathrm{u}-4(\mathrm{~g})(4)(\mathrm{A})(\mathrm{ii})$. The possibility of being saddled with such additional payments arguably tempers to some extent the bargaining strength that the PSLRA confers upon defendants in settlement negotiations. Nonetheless, with respect to the first category focusing on individual net worth and its relation to the damages levied, uncertainty frequently may prevail as to the number of plaintiff-class members eligible to invoke this category. In addition, even with respect to an additional $50 \%$ payment potential, this liability exposure is mild when compared to the invocation of joint and several liability in the pre-PSLRA era. In sum, enactment of PSLRA will likely produce major benefits to defendants in the negotiation process. See Pincus, supra note 19, at 23; supra notes 36-44 and accompanying text.

203. PSLRA, supra note $11, \S 21 \mathrm{D}(\mathrm{g})(4)(\mathrm{B}), 15$ U.S.C. $\$ 78 \mathrm{u}-4(\mathrm{~g})(4)(\mathrm{B})$.

204. Id. $\$ 21 \mathrm{D}(\mathrm{g})(6), 15$ U.S.C. $\& 78 \mathrm{u}-4(\mathrm{~g})(6)$.

205. Id. \& $21 \mathrm{D}(\mathrm{g})(4)(\mathrm{C}), 15$ U.S.C. $\$ 78 \mathrm{u}-4(\mathrm{~g})(4)(\mathrm{C})$. To the extent that a covered person is required to make an additional payment pursuant to the reallocation scheme, that covered person may recover contribution:

(A) from the covered person originally liable to make the payment; (B) from any covered person liable jointly and severally [under the newly circumscribed joint and several liability scheme]; (C) from any covered person held proportionately liable pursuant to this [scheme] who is liable to make the same payment and has paid less than his or her proportionate share of that payment; or (D) from any other person responsible for the conduct giving rise to the payment that would have been liable to make the same payment. 
[Vol. 50

\section{CONCLUSION}

Title II of the PSLRA provides a new liability regimen that significantly confines the joint and several liability framework. The emergence of proportionate liability in 1934 Act suits greatly alters the dynamics of the settlement process. Notably, however; all cases filed prior to December 22, 1995 will be governed by the common law partial settlements and joint and several liability regime. Moreover, the 1995 legislation, with the exception of outside director liability under Section 11 of the 1933 Act, does not directly impact state or federal non-1934 Act litigation. Thus, it remains to be seen to what extent the federal and state courts adopt the framework set forth in the Litigation Reform Act pursuant to statutes and common law causes of action that are not within the PSLRA's parameters.

Id. $\$ 21 \mathrm{D}(\mathrm{g})(5)(\mathrm{A})-(\mathrm{D}), 15$ U.S.C. $\$ 78 \mathrm{u}-4(\mathrm{~g})(5)(\mathrm{A})-(\mathrm{D})$. 